\title{
OS SIGNIFICADOS DO TRABALHO: PRODUÇÃO DE VALORES COMO PRODUÇÃO SEMIÓTICA NO CAPITALISMO INFORMACIONAL
}

THE MEANING OF LABOUR:THE PRODUCTION OF VALUES AS A SEMIOTIC PRODUCTION IN INFORMATIONAL CAPITALISM

Marcos Dantas 1

Resumo Em qualquer indústria, os processos de trabalho tornaram-se, no capitalismo avançado, essencialmente semióticos, isto é, o trabalhador, ao longo da cadeia produtiva que vem desde a engenharia até o ajuste e controle das máquinas, é empregado para processar informações às quais pode atribuir significados relacionados às suas situações concretas de trabalho. A compreensão desse processo ajuda a entender o conceito marxiano de trabalho concreto e pode contribuir para uma melhor compreensão da natureza do capitalismo informacional que emerge neste início de século.

Palavras-chave trabalho concreto; trabalho vivo; trabalho semiótico; informação; molde; Marx.

\begin{abstract}
In advanced capitalism, in all industries the labour process has become essentially semiotic, that is, in all steps of the productive chain, from engineering to machine adjustment and control, workers are employed to process information to which they can attribute meanings related to concrete labour situations. Understanding this process helps to understand the Marxian concept of concrete labour and can contribute to a better understanding of the nature of the informational capitalism that has been emerging in the beginning of this century.
\end{abstract}

Keywords concrete labour; live labour; semiotic labour; information; model; Marx. 
Para José Ricardo Tauile, professor e mestre, com saudades.

"Ninguém pode nada comunicar."

Paul Watzlawick

\section{Introdução}

Pierre Naville, em Vers l'automatisme social, terá sido o primeiro a propor uma investigação sobre a natureza semiótica do trabalho no capitalismo avançado (Naville, 1963), numa linha que encontrou continuidade em Lucas (1974), mas, parece, quase nada avançou em seguida.

Pode-se tentar entender de muitas maneiras essa interrupção. Uma delas é que a sociologia do trabalho que o próprio trotskista Naville ajudou a criar, juntamente com Touraine, Mallet e outros (Maurice, 1998), sofreu uma inflexão a partir de Braverman (1981) e Coriat (1976), deixando de investigar o trabalho operário mais qualificado para se preocupar com o menos qualificado. Seja como for, neste caso, haveria um problema em ambas as orientações: elas não examinam o processo de trabalho em sua totalidade, isolando-o, ao contrário, nas relações que se dão no chão-defábrica, seja naquele altamente automatizado de Mallet, seja na linha de montagem de Braverman e Coriat.

A nossa proposta, ao contrário, busca entender o processo de trabalho e valorização como uma totalidade concreta na qual, conforme já percebia Lukács,

“a diferença entre as atitudes do trabalhador relativamente à máquina particular, do empresário em relação ao tipo dado de evolução do maquinismo e do técnico em relação ao nível de ciência e da rentabilidade de suas aplicações técnicas é uma diferença puramente quantitativa e de grau, e não uma diferença qualitativa na estrutura da consciência" (Lukács, 1989, p. 113, grifos no original).

O "princípio do cálculo" (Lukács) unifica o conjunto, das macro às microdecisões. As diferenças "quantitativa e de grau" hierarquizam os elos contraditórios desse conjunto, dialeticamente amalgamando-os e antepondo-os. Nesta unidade de contrários, o lugar de cada um, desconectados da transformação material imediata, será definido por suas respectivas qualificações para a produção e replicação sígnica. O valor do trabalho, pois, será função de uma dada competência semiótica. Para a acumulação interessará o produto do valor total desse, diria Marx (s/d), "trabalho combinado". Mas cada perfil de trabalho concreto extrairá daí sua parcela proporcional de remuneração, em função de seus respectivos graus de competência. Nisto, 
aliás, nada mudou: a remuneração do trabalho sempre se distribuiu assim, desde os tempos, ou mesmo antes dos tempos, de Marx.

Mas este não é um texto de Economia Política. Do que adiante será lido poderão ser extraídas algumas conclusões-chave para entender a natureza do capitalismo neste início de século XXI. Mas o objetivo deste artigo será delimitadamente tratar do trabalho concreto. A proposta, aqui, é retomar o programa inicial de Naville, para o que contamos já com a relação estabelecida por Umberto Eco $(1980,1981)$ entre signo e trabalho, conforme pudemos testá-la em uma detalhada investigação realizada em duas fábricas brasileiras, uma de transformação e montagem metal-mecânica, outra exclusivamente de transformação.

Este texto divide-se em três partes. Na primeira, retomamos os conceitos propostos por Marx, de trabalho concreto e trabalho abstrato. Na segunda, expomos a nossa investigação sobre o trabalho semiótico. $\mathrm{Na}$ terceira, apresentamos algumas breves conclusões.

\section{Conceitos de valor de uso e valor de troca}

Marx considerava das suas mais importantes descobertas a diferença entre o valor de uso e o valor de troca da mercadoria - inclusive da mercadoria força-de-trabalho. Qualquer mercadoria há que ter alguma utilidade para se lhe atribuir valor de troca. E qualquer mercadoria apenas conterá valor de troca se puder ser útil a alguém.

O problema central da Economia Política estaria relacionado, pois, à impossibilidade de se equalizar trocas com base na utilidade de um bem, dada a subjetividade desta relativamente aos agentes em intercâmbio. Justo porque aquilo que é útil a alguém pode não ter qualquer utilidade a outrem, ou porque a utilidade de um mesmo objeto varia de sujeito para sujeito, seria necessário encontrar uma medida mais objetiva de equalização das trocas, algo que permitisse comparar o valor das mercadorias independentemente de sua utilidade para os agentes. Esta medida, conforme Marx nisto acompanhando e aperfeiçoando uma tradição teórica que remontava a Adam Smith -, seria o tempo de trabalho médio socialmente necessário para a produção de uma mercadoria qualquer.

Também a força de trabalho, como mercadoria, consiste nesta unidade entre valor de uso e valor de troca. O seu valor de uso expressaria o trabalho concreto que alguém pode realizar desde que reúna os conhecimentos, competências, habilidades para atender a uma determinada finalidade. Já o valor de troca expressaria o trabalho abstrato, isto é, "dispêndio de força de trabalho simples que, em média, toda pessoa comum, sem desenvolvimento especial, possui em seu "organismo físico"" ou "dispêndio de força de 
trabalho do homem no sentido 'fisiológico'" (Marx, 1983, p. 51 passim, grifos nossos).

Como medir o valor de troca desta específica mercadoria força-de-trabalho? A esta pergunta, Marx, explicitamente, responde que pelo "quantum de trabalho para produzir a soma média dos meios diários de subsistência do trabalhador" (Marx, 1983, p. 158).

Ou seja, para reapresentar, diariamente, o seu valor de uso no início de sua jornada de trabalho, o trabalhador necessitaria estar com suas energias físicas e mentais repostas. Para isto, ele necessitaria ter-se alimentado convenientemente, ter repousado ou dormido em condições decentes (função das condições de moradia), prover as necessidades básicas da família e do lar, ter gozado, talvez, de algumas horas de lazer e descontração, estar adequadamente vestido para enfrentar o tempo e o clima etc. O somatório do valor de troca das mercadorias que comporiam esta cesta básica de bens de salário forneceria o valor de troca da força de trabalho.

$\mathrm{Na}$ época de Marx, ao aceitar pagar um preço pela subsistência do trabalhador, o capitalista tinha por princípio que este trabalhador estava apto e qualificado para realizar as tarefas que lhe seriam exigidas. O porquê desta aptidão não estaria em questão. De fato, para a realização de grande parte do trabalho industrial empregado até por volta da década de 1870, bastava a formação adquirida no próprio local de trabalho. Geralmente, esta formação começava ainda quando criança ou jovem, na condição de aprendiz, amadurecendo pouco a pouco, no avançar da idade, até a condição de operário qualificado, muitas vezes identificado por Marx, não por acaso, ao "trabalhador adulto" quando, então, o seu valor de uso já se definiria pela condição de experimentado tecelão, oleiro, gráfico, metalúrgico etc. Uma parte destes trabalhadores, adicionalmente, adquiria alguma formação científico-técnica, inclusive bons conhecimentos de matemática básica, em escolas para operários mantidas por sindicatos e associações de classe: cerca de 700 delas funcionavam na Inglaterra por volta de 1850 (Hobsbawn, 1997). Na França, o Estado passou a se ocupar da formação técnica de seus trabalhadores através de liceus politécnicos, os primeiros dos quais criados durante a Revolução Francesa.

A empresa, seja diretamente, através do patrão, seja por seus capatazes ou supervisores (de resto, poucos), quase nada intervinha no processo de produção. O capitalista definia, nas suas relações com o mercado, as metas a cumprir, mas eram os trabalhadores que se distribuíam as tarefas, ajustavam as máquinas, sabiam reconhecer pelo olhar, ou tato, ou outro sentido, os eventuais defeitos em um produto e, por último mas não menos importante, iam, ao longo do tempo, aperfeiçoando os próprios processos produtivos. Ou seja, modificavam máquinas, melhoravam ferramentas, rearrumavam eles mesmos as instalações fabris quando nelas eram introduzidas uma nova 
e mais poderosa máquina a vapor, ou algum novo e mais produtivo equipamento. Vez por outra, de inovação em inovação, alguns deles acabavam criando e introduzindo em alguma indústria um equipamento radicalmente novo, assim causando profundas modificações em todo o processo de trabalho. Estes foram os grandes inventores da primeira revolução industrial, quase todos operários ou artesãos de origem, a exemplo de Maudsley, Stepheson, Nasmyth etc. Em resumo, o conhecimento para a produção era efetivamente detido pelos trabalhadores adultos, não pelos empresários ou por algum corpo técnico especializado.

No processo de trabalho, conforme Marx o conheceu, enquanto o trabalhador se desgasta fisiologicamente, transfere o seu conhecimento e habilidades (seu valor de uso) para o produto, na forma que dá a este produto. O trabalhador detém, em sua mente, uma imagem do produto, e contém em sua mente e no seu corpo, outros conhecimentos, memórias tácitas, habilidades, reflexos adquiridos que serão mobilizados, não raro intuitiva ou inconscientemente, para transformar alguma matéria em algum produto a ser lançado no mercado. Será este conhecimento, não necessariamente formalizado, que, através de movimentos apropriados e, conseqüentemente, do gasto necessário de energia física, o trabalhador transferirá para a matéria em transformação, nela introduzindo uma nova forma adequada ao seu uso.

Marx não somente sublinha a importância desta unidade entre trabalho concreto e trabalho abstrato - valor de uso e valor de troca -, como via nela o ponto de partida do processo de valorização. Não será o mero gasto de energia do trabalhador, reposto pelo seu consumo de subsistência, que acrescenta valor à mercadoria, mas a sua subjetividade em ação, conforme sublinha Rodolsky, lembrando que

“o fator subjetivo do trabalho não somente reproduz o seu próprio valor, como também agrega ao produto um valor novo, um mais-valor. É o único elemento da produção que 'experimenta uma modificação de valor no processo de valorização'" (Rosdolsky, 2001, p. 189).

Esta modificação, com acréscimo, do valor resulta da ação de pôr-emforma o objeto. A mente, através do corpo, apodera-se das formas que encontra disponíveis, opera nelas as transformações desejadas e obtém alguma nova forma, conforme projetara. A mente em-forma o seu objeto, isto é, dá-lhe forma, naquele sentido etimológico do latim informatio, -onis: formação, plano, ação de formar. O valor que o trabalho útil acrescenta aos materiais e meios de trabalho submetidos à sua ação, é a informação que neles introduz. É esta a essência real do trabalho útil, este "dom natural" (Marx) do trabalhador (e de qualquer ser humano) que, entre outras coisas, 
permite ao capital obter mais-valor de materiais quaisquer, ao dar-lhes alguma utilidade. A utilidade da força de trabalho consiste não na sua eventual capacidade de transformar e empregar energia no processo de trabalho, mas na sua capacidade de nele introduzir informação. Mesmo se não considerássemos o processo capitalista de valorização, o processo de trabalho acrescentaria valor aos materiais nele introduzidos, pelo simples ato de acrescentar informação a estes materiais.

Mas, considerando o processo capitalista de valorização, esta diferença dará origem à mais-valia. Deixemos falar Marx:

“Mas o trabalho passado que a força de trabalho contém e o trabalho vivo que ela pode prestar, seus custos diários de manutenção e seu dispêndio diário, são duas grandezas inteiramente diferentes. A primeira determina o seu valor de troca, a outra forma seu valor de uso. $\mathrm{O}$ fato de que meia jornada seja necessária para mantê-lo vivo durante 24 horas não impede o trabalhador, de modo algum, de trabalhar uma jornada inteira. $\mathrm{O}$ valor da força de trabalho e sua valorização no processo de trabalho são, portanto, duas grandezas distintas. Essa diferença de valor, o capitalista tinha em vista quando comprou força de trabalho. Sua propriedade útil, de poder fazer fios ou botas, era apenas uma conditio sine qua non, pois o trabalho para criar valor tem de ser despendido em forma útil. Mas o decisivo foi o valor de uso específico dessa mercadoria ser fonte de valor, e de mais valor do que ela mesma tem. Esse é o serviço específico que o capitalista dela espera. E ele procede, no caso, segundo as leis eternas do intercâmbio de mercadorias. Na verdade, o vendedor da força de trabalho, como o vendedor de qualquer outra mercadoria, realiza o seu valor de troca e aliena seu valor de uso. Ele não pode obter um, sem desfazer-se do outro. O valor de uso da força de trabalho, o próprio trabalho, pertence tão pouco ao seu vendedor, quanto o valor de uso do óleo vendido, ao comerciante que o vendeu. O possuidor de dinheiro pagou o valor de um dia da força de trabalho; pertence-lhe, portanto, a utilidade dela durante o dia, o trabalho de uma jornada. A circunstância de que a manutenção diária da força de trabalho só custa meia jornada de trabalho, apesar de a força de trabalho poder operar, trabalhar, o dia inteiro, e por isso, o valor que sua utilização cria durante um dia é o dobro do seu próprio valor de um dia, é grande sorte para o comprador, mas, de modo algum, uma injustiça contra o vendedor" (Marx, 1983, p. 159-160).

O que Marx nos aponta nesta passagem é a existência de um claro desequilíbrio entre o valor de uso da força de trabalho e seu valor de troca ou, dito de outra forma, entre a grandeza de informação que o trabalho concreto introduz no processo de trabalho e a grandeza dos meios necessários à reposição de sua capacidade abstrata de trabalhar (não estando em questão, por enquanto, definir as respectivas unidades de medida dessas 
grandezas). Ele, em sua época, podia descrever empiricamente o fenômeno, podia afirmá-lo como um fenômeno perceptível, mas não podia avançar além disto, numa explicação mais aprofundada. Nem a isto se propôs. Constatou-o: o que o capitalista compra é a "subjetividade" do trabalhador, trabalho concreto, e esta pode estar à sua disposição durante um dia inteiro, até o limite do cansaço máximo do trabalho abstrato. Sim, porque o trabalho vivo - concreto e abstrato - está contido inseparavelmente em um corpo biológico e este corpo cansa, sente fome, fica doente... O custo da subsistência, ou o valor de troca da força de trabalho, é aquele necessário à reposição da energia dissipada pelo corpo humano, durante processo de transformação da matéria em novo valor de uso. Já o valor de troca deste novo valor de uso assim criado, este resultará de todo o tempo (social médio) durante o qual foi possível manter o corpo do trabalhador ocupado em informar a matéria, em "consumir a forma dada do objeto para colocá-lo em nova forma objetiva, e se consumir a si mesmo unicamente em sua forma subjetiva, como atividade" (Marx, 1973, p. 241)

No século XIX, excetuando-se quase que apenas a indústria têxtil, a produção de uma nova unidade de valor de uso exigia tempo não muito menor que o tempo médio de dissipação da energia física e mental do corpo do trabalhador. E mesmo na indústria têxtil, apesar de seu alto grau de mecanização, a produtividade ainda não era assim tão elevada, se considerarmos os padrões de hoje. Por isto mesmo, então, estender ao máximo possível o tempo de emprego da força de trabalho era a forma mais utilizada de extração de mais-valor: quanto mais tempo o corpo do trabalhador estivesse sendo consumido na obtenção de novos valores de uso, mais a sua utilidade concreta poderia ser empregada na produção de valores de troca superiores ao valor de troca de sua própria força abstrata de trabalho. Por isto, a questão social e política central que praticamente acompanhou Marx durante toda a sua vida era a da luta pela redução das horas de trabalho. O capital nos permite recuperar este histórico (Livro I, cap. 8, 5 e 13, 9). A primeira lei inglesa de redução das horas de trabalho que foi efetivamente obedecida, abarcando apenas as indústrias algodoeira, de linho e seda, data de 1833. A última, já incluindo forjarias e siderúrgicas, é de 1867. A primeira edição d'O capital veio à luz justamente neste ano de 1867. Marx, então, já começava a envelhecer. Como sabemos, morreu em 1883.

Além da extensão do tempo de trabalho, a segunda forma de extração de mais-valia se dava pela redução do custo da cesta básica de subsistência. Obviamente, quanto mais baixo fosse este custo de reposição das energias dissipadas do corpo humano, mantido o tempo total de trabalho, mais o capital poderia extrair sobre-valor do processo de trabalho. Esta redução era possível na medida em que se tornasse mais produtiva e eficiente a produção dos bens de salário, especialmente os alimentos. Com efeito, a intro- 
dução, na agricultura, de fertilizantes nitrogenados extraídos do guano chileno, bem como a expansão da fronteira agrícola, com base em trabalho semi-escravo, em países colonizados de além-mar, daria uma grande contribuição à queda do custo da cesta básica, inclusive favorecendo um longo período de deflação na Europa durante a maior parte do século XIX (Landes, 1994, p. 242 passim).

Tanto a expansão do tempo de trabalho quanto a redução do custo da cesta básica têm limites. Ninguém pode trabalhar 24 horas após 24 horas e, dada uma certa situação política e cultural, boa parte da sociedade, não apenas os operários diretamente interessados, começa a não mais aceitar as jornadas extenuantes de trabalho. Após muitas e, não raro, dramáticas lutas, a jornada de trabalho acabou finalmente fixada em oito horas, em todos os países capitalistas. Já o custo da cesta básica também não pode ser comprimido além de um piso aceitável pelos seus segmentos fornecedores, estes também às voltas com seus próprios custos e lucros. É possível que em fins do século XIX, esses limites já tivessem sido, no geral, atingidos.

No entanto, a mais-valia poderá ainda se estender em uma terceira dimensão: aquela em que "o trabalho supõe dispêndio ampliado de trabalho no mesmo espaço de tempo" (Marx, 1983, p. 116). Isto é, o movimento de informar a matéria em transformação é multiplicado dentro de uma mesma unidade de tempo. Seria como se o capital introduzisse, no processo de produção, um tempo artificial. Numa analogia com o modelo de edificação que levou à expansão das cidades contemporâneas, seria o mesmo que se construir, em um terreno onde cabe uma casa confortável para uma família, um enorme edifício de apartamentos, no qual caberão 20, 30, 40 ou mais famílias. Em um único terreno, multiplicou-se o espaço. Do mesmo modo, o capital logrou replicar o trabalho, de modo a imprimir em uma enorme massa de materiais postos para serem transformados, em uma mesma unidade de tempo, uma mesma e única forma predefinida. É isto que fará o sistema de maquinaria, a partir de um componente especial e fundamental denominado molde. É o assunto do próximo item.

\section{A produção total}

O molde industrial é um conjunto articulado de blocos e peças de metal, plástico ou outro material que permite a uma máquina cortar, furar, dobrar, extrudar, enjetar, moldar de alguma maneira uma matéria-prima qualquer. Nesta matéria-prima será impresso um desenho exatamente conforme projetado ou idealizado, e, em uma mesma unidade de tempo, reproduzirse-á este desenho em milhares de peças iguais, no limite do tamanho do bloco de matéria-prima utilizada. Este bloco de matéria-prima pode ser 
quilômetros de panos de algodão ou lã embobinados de onde sairão cortes de tecidos tingidos ou estampados; grandes lingotes de alguma liga metálica, de onde sairão as mais diferentes peças e componentes de metais; toneladas de polietileno ou outros materiais plásticos, de onde sairão baldes, recipientes, mangueiras etc. É vasto o universo de matérias-primas utilizadas, em função do valor de uso a produzir, e das tecnologias industriais empregadas. O que unifica todo este universo é dependerem todos, quaisquer que sejam suas diferenças, de algum tipo de modelagem, resultando esta modelagem de todo um trabalho prévio de projeto e fabricação de moldes, trabalho este que emprega grande quantidade de trabalho vivo altamente qualificado: engenheiros, desenhistas, programadores de computador, operários-ferramenteiros, técnicos dos mais diversos etc.

Esquematicamente, como convém a um artigo de reduzidas dimensões, esse trabalho vivo que produz e, também, utiliza os moldes se organiza conforme as fases descritas a seguir (Figura 1).

Na fase 1, cria-se o novo modelo. Uma firma, através, obviamente, do trabalho vivo de seus agentes de interação com o mercado e com a sociedade (executivos, vendedores, pesquisadores etc.), identifica a necessidade de um novo produto, ou de introduzir mudanças em algum produto em linha. A origem dessa identificação é bastante aleatória: sugestões de clientes, surgimento no mercado de algum novo modelo lançado pela concorrência, leitura de revistas e catálogos, oferta de novo tipo de matéria-prima ou insumo etc. Por isto, o trabalho vivo necessário para perceber, identificar, atribuir significados a esses eventos necessita ser bem qualificado e estar dotado dos necessários recursos intelectuais-cognitivos para capturar e processar uma gama variada de informações que podem chegar a todo instante e de qualquer fonte. Estas informações se apresentam sob formas dialógicas, escritas, pictóricas, ou ainda outras. Não importa a forma, todas elas são sígnicas: constituem textos significantes (falados, escritos ou figurativos) capazes de serem compreendidos pelos agentes, textos estes que podemos analisar, se for o caso, conforme as categorias e conceitos das teorias semióticas.

Figura 1

A produção total

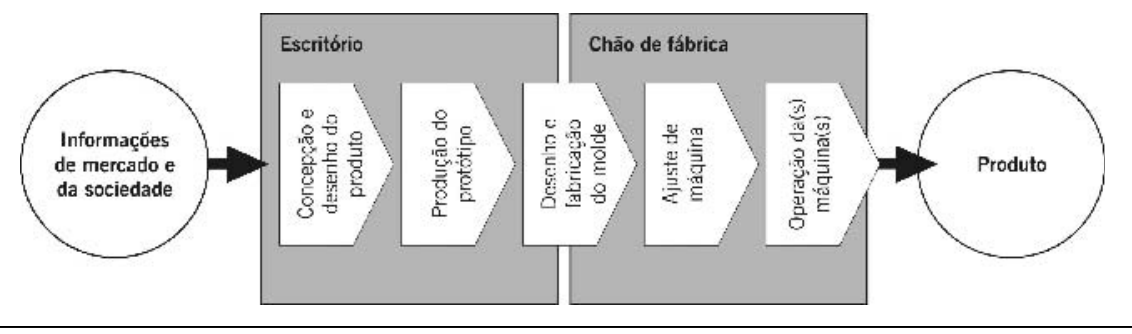


Na fase 2, gera-se o protótipo. Reuniões (isto é, encontros dialógicos), anotações, rabiscos ou rascunhos em papel, em quadro branco de parede, tela de computador, todo um processo de trabalho quase exclusivamente sígnico, traduz as idéias iniciais em uma idéia de produto. Os trabalhadores concretos que intervêm nessas discussões necessitam ser competentes para considerar não apenas as informações recebidas do mercado, mas também aquelas que recebem ou já conhecem da firma onde trabalham: orçamento disponível, matérias-primas ou insumos com os quais estão mais habituados a trabalhar, tecnologias disponíveis na fábrica ou em seus fornecedores, qualificações de sua mão-de-obra fabril etc.

Durante o processo se dá, claro, desgaste natural dos corpos dos trabalhadores envolvidos nessas tarefas (não há quem não necessite dormir, se alimentar etc.), consumo de papéis, lápis, energia elétrica etc., ou seja, transformação material ou, mais rigorosamente, dissipação de energia. Simultaneamente dá-se, também, produção crescente de informação em formas significativas, a partir de informações passadas, ou conhecimento. Estamos começando a identificar aqui, um tipo de trabalho do qual Marx quase não trata em sua obra: o trabalho de produzir informação significativa a partir de informação significativa passada. Para este trabalho, o processamento ou desgaste de matéria será apenas uma mera, secundária, embora inevitável, conseqüência. De fato, no século XIX, este trabalho se fazia numa relação dialógica direta entre o empresário (que comprava e vendia) e seus trabalhadores mais experientes. Parecia um dado da realidade. Desde primórdios do século XX e, cada vez mais, já não é bem assim.

Uma vez especificado o produto, isto é, definidas signicamente, através de textos, desenhos, gráficos, outras formas de expressão, as suas futuras características materiais, será necessário, na maioria das indústrias, construir-se um primeiro modelo deste produto. Esta construção, não raro, assemelha-se a um trabalho artesão, com forte interação imediata entre os projetistas e os materiais com os quais estão trabalhando. Noutras palavras, faz-se aí o que o senso comum entende por "trabalho manual". Neste trabalho se envolvem inclusive e principalmente cientistas e engenheiros, além de outros técnicos qualificados. Hoje em dia, é verdade, depois do advento e desenvolvimento da informática, boa parte deste trabalho pode ser realizado através de sistemas computacionais, o que dele faz ainda mais exclusivamente sígnico. Mas durante a maior parte do século XX, antes do advento dos computadores, era um trabalho de construção de maquetes ou modelos em escala, moldagem de uma ou poucas peças individuais, pintura a mão de algum tecido, atividades assim que exigiam, além de conhecimentos conceituais, também habilidades corpóreas ("manuais") dos técnicos aí envolvidos. 
Esses modelos e peças são submetidos a vários testes. Alguns se referem às suas características físicas e químicas - isto é, materiais. É preciso saber se suas formas, desenhos, cores, resistem às máquinas que os fabricarão e, principalmente, aos usos concretos que terão. Na produção de um avião, num entre muitos exemplos, é necessário saber se o modelo em escala resiste bem às (piores) condições de vôo que deverão ser enfrentadas pelo avião real, algum dia. Na produção de uma peça metálica qualquer, será necessário saber se uma determinada curva, muito bonita - "genial!" -, prevista no desenho original, pode vir a ser realmente fabricada pelos equipamentos disponíveis na fábrica, ou com os materiais fornecidos pelos fabricantes de insumos. Tudo isso implica testes, cálculos, anotações, maciça utilização de conhecimentos, experiências, habilidades do trabalho vivo que conduz esta fase do processo produtivo. Estes testes, às vezes, são demorados: podem durar, como no caso do avião, vários anos. E podem custar até alguns milhões de dólares.

Além dos testes materiais, na sociedade capitalista contemporânea é necessário submeter a maioria dos valores de uso ainda em projeto, a um segundo tipo de teste: aceitação pelo mercado. Isto seria impensável na época de Marx. Algum fabricante produzia panelas; outro, camisas; ainda outro, cadeiras ou carroças, o que quer que fosse, mas nenhum daria maior importância ao design, ao visual estético, à moda, aos gostos. Ainda na época de Ford, podia ser assim, haja vista a sua famosa frase: "Você pode fabricar o carro na cor que quiser, desde que seja preta"... Mas já de muito tempo, o valor de uso incorporou, também, um valor estético. Máquinas e outros valores de uso intermediários podem ainda, talvez, ser fabricados considerando apenas as suas funcionalidades. Mas os valores de uso finais, aqueles para onde converge, ao fim e ao cabo, toda a cadeia produtiva, conterão obrigatoriamente valores estéticos, a eles atribuídos pelos contextos e circunstâncias da sociedade em que vivemos. Há uma extensa, diversificada, nem sempre convergente, quase nunca consensual literatura a respeito, que não pode mais ser ignorada nem pela Economia Política nem por outros estudos sobre trabalho e produção, numa discussão crítica sobre as condições atuais do mercado e da nossa sociedade. Citemos, entre outros, a título de exemplo, sem que isto expresse, pelo menos aqui, qualquer outro compromisso com as suas teses, Bourdieu (1982), Baudrillard (s/d), Débord (1997), autores aliás que pouco têm em comum entre si, mas que nos ajudam a iluminar aspectos fundamentais da sociedade, sobretudo do mercado consumidor, em que vivemos.

A produção do protótipo será por isto, também, uma obra de arte. Nela, valores estéticos estão involucrados desde o primeiro momento, daí porque, entre os trabalhadores necessários a esta fase do processo, encontram-se 
aqueles cujo valor de uso incorpora formação de arquiteto, de desenhista industrial, ou similares.

O protótipo, uma vez concluído e aprovado, será uma peça única. A etapa seguinte será a de reproduzi-lo na maior quantidade possível, em uma mesma unidade de tempo. Ou seja, fabricar a mercadoria que ele promete ser.

Na fase 3, fabrica-se o molde. Moldes podem ser de vários tamanhos e formatos. Na indústria metal-mecânica, costumam ser pesados blocos metálicos que necessitam da ajuda de carrinhos de mão para se os carregar. Numa indústria de confecção de roupas, podem ser leves peças de madeira ou papelão, no formato dos cortes das roupas. Ou podem ser, também, em outras indústrias, blocos de algum material plástico resistente. Importante é que, uma vez adjudicado o molde a uma máquina, esta máquina vai produzir exatamente aquilo que o molde permite que ela produza.

A fabricação de um molde consiste em um processo de trabalho que se inicia com a reprodução do protótipo em um desenho ou esquema (ou vários desenhos e esquemas). O protótipo, recorde-se, é um objeto material. Uma equipe técnica para tal qualificada transforma as formas do protótipo em formas de desenho. Esta equipe domina um código, em parte aprendido durante a sua formação técnica, em parte desenvolvido e consolidado no próprio ambiente da empresa, que permite relacionar os diferentes formatos, componentes, espaços entre partes, volumes, cantos e contornos, tudo isto que existe em qualquer objeto real, a linhas inteiras ou tracejadas, circunferências, ângulos, polígonos, cubos, sombreados, cores que representam as diferentes formas contidas no protótipo. Se o protótipo é um objeto material concreto, o desenhista transformou-o numa representação sígnica, conforme um código muito particular do seu contexto fabril. Até alguns poucos anos atrás, este trabalho de produção sígnica costumava ser realizado por todo um departamento de desenho que, nas maiores empresas, podia reunir mais de centenas de técnicos. Hoje em dia, é um trabalho que pode ser realizado, em grande parte, com ajuda de uma estação informatizada de desenho (CAD) - logo, com muito menos gente. Mas a natureza em si do trabalho não mudou: trata-se de produção de informação sígnica.

De posse desses desenhos, uma equipe de trabalhadores qualificados começará a fabricar os moldes. Dependendo do tipo de indústria e do tipo de produto, são necessários um, poucos, ou muitos moldes para fabricar um produto total. Na pesquisa feita por este autor, na qual se baseia este artigo (Dantas, 2001b), a fábrica investigada fabricava um produto com muitos componentes, sendo necessário existir um molde para cada componente. Cada produto novo, portanto, engendrava a fabricação de um punhado de novos moldes. 
A fabricação de um molde é um trabalho comparável à realização de uma escultura artística, exceto pela óbvia ausência, aqui, de maiores preocupações estéticas. Mas ela se inicia com uma ação sobre alguma matériaprima bruta - um bloco de metal, por exemplo - na qual são recortadas as formas previstas e determinadas pelo desenho. Os trabalhadores que executam essa tarefa servem-se de máquinas de propósito geral, com as quais podem cortar, desbastar, furar, lixar etc., os componentes do molde. Para executar suas tarefas, os trabalhadores lêem os desenhos, interpretam seus signos e ainda, necessariamente, realizam vários cálculos para estabelecer as distâncias, os ângulos, outras medidas que deverão ser obedecidas pela máquina, na transformação da matéria.

Acompanhemos, por exemplo, este depoimento de um fresador, com formação no Senai e diploma de segundo grau:

“Eu tenho que estudar o desenho primeiro, para saber por onde eu posso começar [a cortar a peça]; qual a primeira operação que devo fazer; se eu posso começar pelo lado $x$ ou $b$. Se tem um furo aqui e se eu fresar em volta, pode ser que eu não tenha como furar depois, que eu não tenha como prender a peça para furar depois. Neste caso aqui, a peça tem muito detalhe, é muito trabalhosa. Então, neste caso, eu teria que começar fazendo o furo, se não depois seria pior para prender a peça na mossa ali, e fazer o furo. Ela retangular é bem mais fácil [de prender na mossa]. Depois, eu sigo para as outras etapas. Este rasgosinho aqui, depois os graus. Para medir os graus, a gente bota no transferidor. Aqui tem 15 graus. Aqui também tem 15 graus. Neste caso aqui, aqui pede, até aqui, 26,2. Eu traço, no graminho, 26,2, daqui até aqui. Aqui tenho que fazer outra continha: dá 19,5. Ai vou saber até onde posso contar o grau. Vou para o transferidor, boto onde tracei no graminho, aí dou um tracinho com o riscador. Aí freso até chegar em cima da linha ali" (Dantas, 2001b, p. 395).

Não importa se a fala deste trabalhador pouco permite, a um não iniciado, ou a um leitor fora daquele contexto, uma clara compreensão da sua mensagem, especialmente quando ele se refere a medidas, sem nem se preocupar em definir a unidade dessas medidas, provavelmente centímetros. $\mathrm{O}$ que está evidente é o seu trabalho de transcodificar linhas e números que vê em um desenho, em números e linhas que vê e traça na peça metálica, através de instrumentos como o graminho, transferidores, compassos, outros medidores, ou diretamente na máquina em que está trabalhando. Isto não é um trabalho de mera execução: exige interpretação de signos; exige definir e realizar operações matemáticas, logo, operações simbólicas; exige estabelecer autonomamente a seqüência de fases que imprimirá ao seu trabalho, logo, conceber; exige, por fim, habilidade e precisão no manejo de instrumentos especializados, logo, qualidades artesanais. Entre estes instru- 
mentos vê-se um inventado pelos próprios trabalhadores: uma espécie de régua de cálculo de papelão contendo um conjunto de funções trigonométricas, necessárias à determinação dos ângulos de fresa. Que os operários não queiram fazer tais cálculos mentalmente, em nada diferem dos engenheiros que, para encontrarem os resultados das suas contas, usavam, no passado, réguas-de-cálculo e, hoje, usam calculadoras eletrônicas ou planilhas de computador. O importante é entender o problema e saber localizar a fórmula matemática exata para resolvê-lo. As operações aritméticas do cálculo, sejam simples ou complicadas, qualquer instrumento, de madeira, papelão, ou de pecinhas de silício, pode e deve fazer. Sobra mais tempo para a mente pensar e criar.

Assim como boa parte do desenho do produto pode ser, hoje em dia, executada com ajuda de computador, da mesma forma a informática também vem causando uma mudança na forma de realização do trabalho ferramenteiro, ao incorporar as suas máquinas a um equipamento de controle numérico. Mesmo assim, com este novo equipamento, tanto quanto antes, o trabalhador continua sendo leitor e intérprete de signos, agora na condição de programador da máquina, cujas operações comanda através de teclados de computador - ou seja, ampliam-se as dimensões do trabalho de produção sígnica. Numa empresa mais avançada tecnologicamente, pode-se admitir que, hoje em dia, a estação de desenho estará diretamente conectada às máquinas-ferramentas que fabricam o molde. Esta conexão, eventualmente, terá suprimido o trabalho prático do ferramenteiro, ou, numa linguagem marxiana, terá anulado e feito desaparecer o seu valor de uso - logo, o seu valor de troca. Por outro lado, ele será substituído pelo trabalho vivo concreto de um ou alguns programadores de sistemas, capazes de realizar o desenho e de controlar todo o processo subseqüente de produção automática dos moldes.

Independentemente das transformações tecnológicas e sociais que a informática possa estar introduzindo no processo de trabalho, o que se está evidenciando aqui é a natureza sígnica que este trabalho já assumira muito tempo antes de sequer surgirem os primeiros computadores, pois todo esse processo resulta de arranjos produtivos fabris e de tecnologias de produção desenvolvidas e consolidadas pelo menos desde as primeiras duas décadas do século XX. Na fábrica que nos serviu de exemplo, suas máquinas, com algumas exceções, datam de mais de 40 anos e sua história, bem como a de seu principal produto são quase centenárias.

No entanto, é verdade, vários elos desta cadeia de trabalho vivo sígnico-material são suprimidos pelo processo de informatização, isto é, são substituídos pelo trabalho morto de processamento da informação. Tal deslocamento pode provocar na sociedade real muitos dramas pessoais ou sociais, ao suprimir postos de trabalho. Ao mesmo tempo, permite, também, 
emergir novos perfis de trabalhadores, com suas competências próprias e renovadas aspirações sócio-culturais. Não queremos discutir, neste artigo, estas mutações. Registramos tão-somente que, na sua essência, o trabalho vivo não está desaparecendo por força da informatização. No entanto, evolui, cada vez mais, para formas de trabalho que requerem elevada competência cognitiva do trabalhador no processamento de informação significativa, vale dizer, no uso e na geração de conhecimentos produtivos.

Na fase 4, ajusta-se o molde à máquina. A máquina é constituída por um conjunto de mecanismos capazes de se movimentarem em diferentes direções e velocidades, orientados pelo molde que dará a forma precisa a uma peça qualquer. Deste modo, com um único molde orientando milhares de movimentos repetitivos da máquina, dezenas, ou centenas, ou milhares de peças iguais podem ser produzidas em um minuto, ou uma hora, ou um dia, qualquer que seja a unidade de tempo.

Um conjunto que pode chegar a conter centenas de diferentes moldes expressa um "produto total" (Marx) e permite fabricar milhares de produtos totais em uma mesma unidade de tempo. O trabalho de transformação direta da matéria ou de produção de novos valores de uso é realizado pelo conjunto de moldes fabris acoplados às máquinas e, durante este tempo de transformação, o trabalhador pouco mais terá a fazer do que observar o comportamento da máquina, buscando prevenir erros e defeitos.

Como bem o sabem os engenheiros, operários e qualquer pessoa com um mínimo de cultura fabril, a colocação e posicionamento de um molde na máquina não é uma atividade trivial e instantânea. Sempre se faz necessário executar um conjunto de procedimentos de ajuste do molde à máquina. No jargão fabril, diz-se, num inglês aportuguesado, "setape da máquina" (de set up). Este processo, aliás, serviu de base à investigação de Burawoy (1979) sobre o "consenso de fábrica", e toda a sua conseqüente crítica às idéias de Braverman (1981). Burawoy descreve como, durante o "setape", os operários (pelo menos, os operários estadunidenses) põem-se a "jogar" com a máquina, buscando ajustá-la nos limites máximos da capacidade de trabalho dela, máquina, assim lhe extraindo a maior produtividade possível. Esta competência para obter o melhor ajuste de máquina atribuía aos trabalhadores por ele investigados, não somente algum prêmio monetário pelo ganho de produtividade obtido, como também um "reconhecimento entre os pares", que se expressava, como poderia dizer Bourdieu (1983a; 1983b), em acúmulo de "capital simbólico no campo fabril".

A nossa investigação não busca confirmar a tese de Burawoy, mas demonstrar como, de qualquer modo, o processo produtivo é um processo permanente de produção de significados, iniciando-se nas fases de projeto e prototipação do produto e avançando por todas as suas fases de fabricação e montagem. Neste texto, somente podemos abordar alguns segmentos do 
processo total. No caso do "setape", uma das fases mais importantes de todo o processo, o operário encaixa o molde na máquina, aperta seus parafusos, introduz a matéria-prima, e a faz produzir apenas uma, duas, três ou quatro unidades da peça a ser fabricada. Em seguida, avalia o resultado. Se julga que o resultado não está "bom", corrige algum detalhe do ajuste e, novamente, faz a máquina produzir uma, ou duas, ou três unidades da peça. Repete este procedimento quantas vezes for necessário, até julgar que a peça está finalmente saindo "boa", indicando estar o molde corretamente ajustado à máquina. Só então "dispara" a produção. A partir daí, nada mais lhe restará a fazer do que permanecer observando o trabalho morto da máquina. E se permanece observando este trabalho, é porque, como veremos adiante, sempre podem ocorrer eventos inesperados, que lhe exigirão intervir no processo produtivo, às vezes até mesmo interrompendo-o.

O trabalho vivo combinado, corporificado em cada operário individual, não se limita, pois, a meramente executar tarefas determinadas. Cabe-lhe um conjunto de atividades mentais de avaliação, julgamento, análise e, por fim, de decisão sobre a situação em que o trabalho morto, corporificado em cada máquina, estará de fato pronto para executar a operação desejada.

Obtivemos de um operário de uma fábrica metal-mecânica a seguinte descrição de suas atividades, diante de uma dificuldade para ajustar uma enorme prensa para o trabalho de estampar duas pequenas peças com pouco mais de 10 por 6 centímetros. Ele andava de um lado para o outro à volta da máquina, mexia várias vezes no molde, introduzia entre os seus blocos um pedaço de chapa metálica, apertava o botão que punha a prensa em movimento, interrompia logo em seguida a operação, conferia o resultado e deixava claro a sua insatisfação. Ele explica:

“Quando eu boto na máquina, eu costumo regular pelo carimbo, por aqui. Conforme fui regulando pelo carimbo, eu vi que ela não deu a medida desse repuxo aqui e nem cortou aqui. Aí eu vi que estava errado. Essas duas de cá são as peças erradas. Tinha que ter o corte lateral e o repuxo tinha que estar na medida. Aqui não está na medida, a medida certa é esta, pode ver que tem diferença" (Dantas, 2001 b, p. 436 passim). 
Figura 2

As imagens significativas de um "setape"

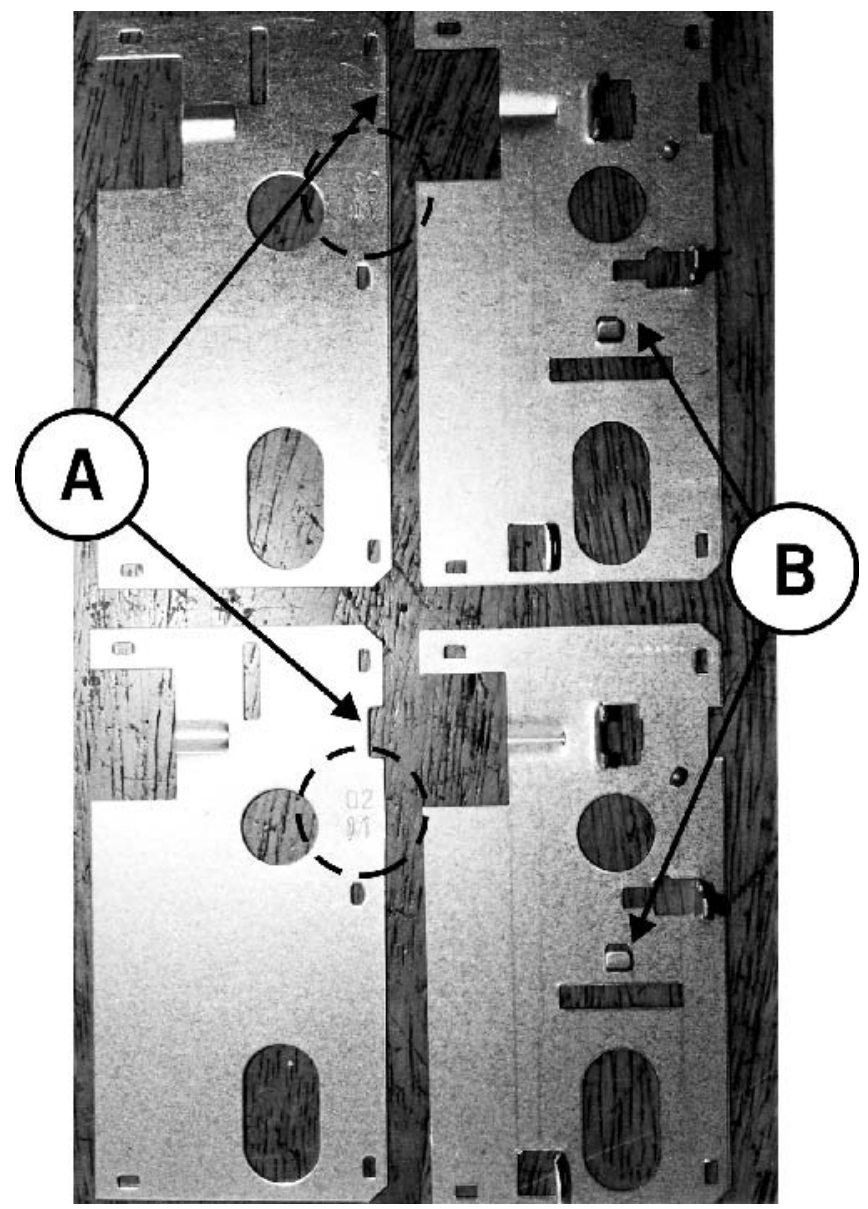

O "carimbo", conforme assinalado por um círculo pontilhado na Figura 2, é um código numérico de identificação da peça. A nitidez da forma do carimbo (na peça de baixo, na foto) é o primeiro elemento que o operário observava, para conferir se o molde estava bem ajustado. Se o "carimbo" não estiver "nítido" (na peça, em cima), o ajuste "não está bom". Entretanto, neste caso, quando, após algumas tentativas, obteve o carimbo nítido, observou que um elemento denominado "repuxo" (identificado pela letra B) não apresentava (na peça de cima) a forma desejada (conforme a peça de baixo, na Figura 2): "não deu a medida", disse ele. Também "faltou um corte aqui", acrescentou, apontando para o local (letra A, peça de cima), onde deveria ser feito o corte (letra A, peça de baixo). Isto é, dois outros elementos também lhe serviram como formas a exprimir o correto ajuste de máquina. O fato de uma pequena lingüeta ("repuxo") não apresentar exata- 
mente o contorno desejado (na foto) e de estar faltando um recorte ("corte") numa das peças significou, para o operador, a emergência de um problema no molde - um evento aleatório a lhe exigir alguma interpretação:

“Eu começo a regular pelo carimbo, eu achava que era só botar um calço aqui, para o macho entrar mais e cortar. Coloquei de novo lá e não foi isso. Aqui cheguei a conclusão que era aqui, que o macho não estava batendo o suficiente para dobrar. Esta foi a primeira, essas duas aqui, a caixa e a tampa. Conforme estampei, eu vi que não tinha saído corte aqui, e este repuxo estava muito alto. Tinha que achatar mais para ficar na medida" (Dantas, 2001b, p. 436 passim).

O trabalhador parece seguir uma seqüência de tentativa-e-erro - não há rotina aqui. Obviamente, a sua experiência indica que as soluções tentadas, em princípio, devem dar certo. E o "dar certo" será definido, conforme repete, pelo estado final dos "carimbo", "repuxo" e "corte". Mas, de cada tentativa, ela vai extraindo significados que nos revela através de frases como "o macho [um componente do molde] não estava batendo o suficiente para dobrar", ou então, que "tinha que achatar mais para ficar na medida". Durante esses testes, ele nos apresenta uma 'ordem de leitura':

“Repuxo e carimbo, os dois. Os dois têm que sair perfeitamente. Quando eu coloco na máquina, em primeiro lugar eu regulo pelo carimbo. O carimbo estava bom... [mas ele percebeu a] falta do repuxo e do dente. Quando eu coloco a ferramenta na máquina, antes de colocar a chapa para começar a estampar, eu coloco um pedacinho de chapa no carimbo, onde eu passo o carimbo, só o carimbo. Aí quando eu vejo que o carimbo está mais ou menos dentro disso aqui que o senhor está vendo, aí coloco a chapa. Aí quando eu começo a estampar, eu vejo o carimbo" (Dantas, 2001b, p. 436 passim).

Começa a emergir o código que permite a comunicação entre o trabalhador e a sua máquina. Adotando, a partir daqui, uma simbologia semiótica adaptada de Eco (1980)2 , o \carimbo\, a \lingüeta \, o \corte \são marcas topossensitivas pelos quais o operário se orienta, na busca do <ajuste de máquina $>$. Estas marcas, sendo elementos e arranjos determinados e necessários, fornecem-lhe a forma sintática do código. A ausência de quaisquer delas já denunciaria um erro de sintaxe.

No entanto, o operador estabeleceu também uma direção de leitura. Está claro que ele "visa primeiro o carimbo". Em princípio, se numa chapa de amostra o |carimbo| estiver /nítido/, ele espera que os demais elementos não apresentem problemas. Mas ele não parece confiar inteiramente neste único elemento. Estampa uma amostra de toda a peça, e confere o $\mid$ repuxo $\mid$ e também o $\mid$ dente $\mid$. A percepção dessas formas lhe fornecerá o 
significado de <arranjo de máquina $>$ na circunstância desta específica tarefa. Este significado, que somente emerge do arranjo conjunto daqueles elementos (isto é, do texto), pode ser e, no início, quase certamente será, /ainda não está bom/. Nos testes seguintes, mudará para /melhorou/. Até alcançar /está bom, "pau na máquina"/... a não ser que, como às vezes acontece, o problema seja mais grave e o trabalhador tenha que recorrer à assistência de outros departamentos da fábrica, para corrigi-lo.

O trabalho de ajuste da máquina visa, portanto, obter um primeiro exemplar da peça a ser fabricada, no qual esteja fielmente projetada a imagem que, dela, o operador faz mentalmente - e assim reaparece (como se tivesse algum dia desaparecido...) o "fator subjetivo do trabalho" no chãode-fábrica. Este tempo de "setape" é um tempo durante o qual revelam-se eventos que significam não estarem inteiramente de acordo o código com o qual opera o trabalho vivo e o código (rigorosamente sintático) com o qual opera o trabalho morto. Este desacordo provoca um tempo extra, aleatório, no processo, tempo, sublinhe-se, durante o qual o capital não está produzindo. E que, por isto mesmo, ressalte-se, é tempo durante o qual o capital atribui valor ao trabalho vivo, individual e coletivo, na medida e nas dimensões de sua competência e qualificação para identificar e extrair significados, o mais rapidamente possível, dos eventos indesejados ou inesperados que emergem do processo mesmo. É nesta competência para tratar significativamente a aleatoriedade, no menor tempo possível, seja no nível de um operador de prensa ("operário"), seja no nível de um operador de CAD ("técnico"), seja no nível de um operador do mercado ("vendedor"), que se encontra o valor produtivo do trabalho vivo, para a valorização e acumulação do capital. Obviamente encontramo-nos aqui diante de uma lógica distinta daquela estudada por Marx, embora dela derive diretamente por via do seu conceito de mais-valia através da intensificação do trabalho, ou replicação do tempo de produção para um mesmo movimento produtivo.

Nesta lógica, enfatize-se, cabe ao trabalho vivo produzir significados, processando significativamente os eventos que ocorrem durante o processo. O trabalho da máquina, por sua vez, é o de realizar a transformação material, subordinada aos significados que o trabalho vivo deseja obter desta transformação.

Na fase 5, a última, a máquina trabalha, o operário, em princípio, observa, mas... Aqui, exibiremos um exemplo obtido em uma fábrica produtora de fibras óticas. Nesta fábrica, durante esta fase de transformação, também a relação imediata do trabalho vivo com o trabalho morto é quase toda ela exclusivamente sígnica. O único momento de contato táctil, "manual", dos trabalhadores com a matéria em transformação se dá justo durante o "setape", quando um tarugo de vidro de altíssima pureza, medin- 
do cerca de um metro de comprimento por 20 centímetros de diâmetro, é instalado no alto de uma torre com 10 ou mais metros de altura. Como todo "setape", este também contém seus desafios. Mas, uma vez concluído, todo o restante do processo será acompanhado, pelo operário, através dos mais diversos sensores, relógios, medidores e pela tela de um computador. Qualquer intervenção do trabalhador se dará, também, quase sempre, através do teclado do computador.

A fase do processo que aqui nos interessa consiste em esticar, ao longo da torre, a partir do tarugo instalado, um fio de vidro que, ao final, será mais fino que um fio de cabelo. $\mathrm{O}$ fio desce pela torre a uma velocidade superior a 700 metros por segundo. Diante do olhar humano menos atento, ele parece estático. Além do mais, é translúcido, como deve ser qualquer vidro de altíssima qualidade.

Uma vez aconteceu de um operário perceber, por acaso, uma luz esverdeada piscando no fio. Ela aparecia e desaparecia em frações de segundo. O operário viu-se diante de uma marca topossensitiva que, não devendo ocorrer alí, só poderia significar /algum defeito/, ou /algum problema/. No caso, graças à sua experiência, ele imediatamente deduziu um segundo significado deste evento: tratava-se da presença de microscópicas bolhas de ar no interior do fio de vidro. Daí ele extraiu um terceiro significado, este de natureza pragmática: deveria comunicar o problema a alguma chefia, visto que, quase certamente, a ocorrência lhe exigiria a paralisação do processo para correção do defeito (Dantas, 2001b, p. 353 passim).

Como já dissemos acima, quase todo o trabalho fabril, a partir do momento em que a máquina está operando a plena velocidade, reduz-se a um observar rotineiro que somente será interrompido se, da máquina, originase algum evento imprevisto, possivelmente problemático. O trabalho do operário, então, será o de atribuir significados a este evento. De pronto, ele deverá reconhecer, no evento, um /problema/, ou /defeito/, ou então, ao contrário, algo que não lhe mereça maior atenção: /nada que preocupe/. Em um crescente processo de produção de significados, ele deverá tentar identificar melhor a natureza da dificuldade, se for o caso, e, nisto, também definir as ações que deverá executar. Pode modificar o comportamento da máquina através de teclados e manivelas; pode até paralisá-la; pode tentar corrigir ele mesmo o defeito; pode concluir que necessitará da ajuda de outros colegas, do pessoal da manutenção, de uma equipe de engenharia etc.

A experiência, ou conhecimento, do trabalhador pôde atribuir, num tempo imediato, um significado ao evento físico porque ele parecia externo ao padrão esperado, isto é, ao código laboral com o qual se relaciona, no contexto desta fábrica, com a máquina e com os materiais em processamento. Este código não prevê, em princípio, que uma cor esverdeada pisque no 
fio translúcido. Mas se, neste caso, ele pôde, pouco depois, atribuir um significado mais preciso ao evento físico, é porque a possibilidade de uma bolha microscópica se formar no interior do fio está também prevista, embora secundariamente, neste seu código. Talvez ele já tivesse vivenciado isto antes. Mas se não o tivesse, bastaria ter percebido a anomalia para que a sua causa viesse a ser investigada, por outros técnicos ou engenheiros, em testes no laboratório da fábrica.

Em um tempo instantâneo (no limite de zero), o operador pôde perceber que estava diante de um evento significativo que denotava algo. Mas, a partir daí, extrair ou produzir todas as demais significações conotativas relacionadas àquele evento (natureza exata do problema, suas causas, formas de corrigi-lo etc), lhe exigiria um tempo algo maior. Mais do que isto: exigiria a mobilização interativa do conjunto do trabalho fabril, a intervenção de outros técnicos, a presença de engenheiros, os testes de laboratório etc. Dependendo da complexidade do problema, aquele evento, cuja significação foi inicialmente binária e produzida de imediato, poderia vir a se tornar todo um trabalho de processamento de informação e produção de significados, realizado ao longo de várias instâncias da organização empresarial fabril. Será trabalho combinado efetuado pelos homens e mulheres que integram o coletivo fabril, independentemente de que alguém esteja junto à máquina, como o operador do nosso exemplo; outro ocupe um posto em uma bancada de laboratório; uma outra seja a gerente que coordena a comunicação entre o chão-de-fábrica, o laboratório, outros departamentos da empresa; um outro seja um engenheiro que introduz dados em um computador e analisa uma planilha qualquer...

$\mathrm{O}$ valor de uso não somente daquele operário mas do conjunto do trabalho combinado; a sua utilidade, distribuída em suas muitas instâncias, devido à qual o trabalho encontrou o seu emprego nesta fábrica concreta, reside, mais uma vez, na sua competência semiótica e comunicacional, que será tanto maior (e mais bem-remunerada) quanto melhor for a sua capacidade para produzir significados conotativos, a partir de um primeiro evento denotativo - e, nisto, se distinguirá a competência específica, o grau de formação exigido, os salários correspondentes e ainda os títulos distintivos ("operário", "técnico", "engenheiro" etc.) de um trabalhador junto à máquina, de outro na bancada de testes, de outro ainda na estação de projetos etc.

Em suma, o trabalho vivo é e sempre será necessário para perceber e corrigir eventos inesperados junto à máquina, assegurando que ela opere conforme toda uma codificação definida pelo conjunto do trabalho combinado industrial. Para o trabalhador individualmente e para todo o trabalho combinado assim posto em movimento, esses eventos imprevistos ou aleatórios fornecem-lhes motivos para agir. Tais respostas ao inesperado, ao 
aleatório convocam, a todo o instante, a produção de significados e, dependendo da complexidade do problema, podem evoluir até dar origem a alguma importante inovação, ou mesmo uma grande invenção.

\section{O trabalho combinado}

\section{Escreveu Marx no Capítulo VI inédito de O capital:}

“(...) como, com o seu desenvolvimento da subordinação real do trabalho ao capital ou do modo de produção especificamente capitalista não é o operário individual que se converte no agente real do processo de trabalho no seu conjunto mas sim uma capacidade de trabalho socialmente combinada; e como as diversas capacidades de trabalho que cooperam e formam a máquina produtiva total participam de maneira muito diferente no processo imediato de formação de mercadorias, ou melhor, neste caso, de produtos - um trabalha mais com as mãos, outro mais com a cabeça, este como diretor, engenheiro, técnico etc., aquele como capataz, aqueloutro como operário manual ou até simples servente - temos que são cada vez em maior número as funções da capacidade de trabalho incluídas no conceito imediato de trabalho produtivo, diretamente explorados pelo capital e subordinados em geral ao seu processo de valorização e de produção. Se se considerar o trabalhador coletivo constituído pela oficina, a sua atividade combinada realiza-se materialmente e de maneira direta num produto total que, simultaneamente, é uma massa total de mercadorias e aqui é absolutamente indiferente que a função deste ou daquele trabalhador, mero elo deste trabalhador coletivo, esteja mais próxima ou mais distante do trabalho manual direto [grifos nossos]. Porém, então, a atividade desta capacidade de trabalho coletiva é o seu consumo direto pelo capital, ou por outra, o processo de autovalorização do capital, a produção direta de mais-valia e daí, como se há de analisar mais adiante, a transformação direta da mesma em capital" (Marx, s/d, p. 10, grifos no original).

Assim como, por motivos ignorados, Marx excluiu essas linhas da sua versão final d'O capital, também não cumpriu muito bem a promessa de examinar como essa capacidade de trabalho coletivo veio a "se transformar diretamente em capital". Seriam os economistas de linhagem neoclássica que, cem anos depois, redescobririam o "capital humano"...

Pois neste artigo estamos buscando examinar e analisar justo o funcionamento desse trabalhador coletivo, dentro do qual é "absolutamente indiferente" (para o processo "total" de produção e valorização) que este ou aquele trabalhador esteja mais próximo ou mais distante da máquina (logo, da transformação material), que este "trabalhe mais com as mãos", "outro mais com a cabeça", "inclusive como diretor, engenheiro ou capataz", 
porque são cada vez maiores as "capacidades de trabalho" - isto é, os valores de uso do trabalho concreto - que se incluem no conceito de trabalho produtivo - trabalho que valoriza capital.

Se, em termos gerais, este processo está historicamente consumado (e já há muito tempo, antes mesmo da informatização), fica evidente que, para tal trabalho-capital coletivo e combinado, as "funções das capacidades de trabalho" contribuem em diferentes dimensões quantitativas. O que se fez, na investigação aqui relatada, foi mapear essas diferentes contribuições. Este mapa pôde ser elaborado com base em conceitos-chave de teorias da informação e significação, conforme serão apresentados nas seções seguintes.

\section{Incerteza, aleatoriedade, redundância}

Referimo-nos antes à informação - aquela que o trabalhador introduz no objeto, modificando-o e valorizando-o. Entendemos que informação é uma modulação de energia que provoca algo diferente em um sistema qualquer e produz, neste sistema, algum tipo de ação orientada, se nele existirem meios e predisposição para captar e processar os sentidos ou significados daquela modulação. Portanto, uma dada modulação de energia pode ser informação para um sistema e não ser "nada" para outro. O espectro visível do olho humano não é o mesmo, como sabemos, do de outros animais, tanto quanto o espectro auditivo, olfativo etc. Em um sistema fabril, não somente devido a determinadas competências, que são inerentes a uns indivíduos e não a outros (acuidade visual, por exemplo), mas muito em função do conhecimento e da experiência, certos eventos podem ser captados por determinadas pessoas e não o serem por outras.

No mundo social humano, a informação será necessariamente semântica. Isto implica dizer que toda informação está organizada conforme algum código que remete, no limite, a unidades culturais assumidas, compreendidas ou reconhecidas pelo sujeito social (Eco, 1980). As unidades culturais tanto são aquelas comuns a todo um amplo conjunto da sociedade que se identifica em uma nação ou uma língua, como aquelas exclusivas de subgrupos sociais, políticos, profissionais etc. O mundo da produção, naturalmente, está repleto de suas próprias unidades culturais e respectivas expressões significativas, como também as inventa a todo instante.

O universo, mesmo que um tanto difuso, das unidades culturais, está organizado, formal ou informalmente, racional ou emocionalmente, consciente ou inconscientemente, de modo a constituir conjuntos e subconjuntos de códigos sociais e laborais: arranjos convencionados de formas perceptíveis no espaço e no tempo que oferecem a um agente um certo grau de previsi- 
bilidade quanto aos eventos passíveis de serem percebidos por meio desse conjunto de formas. Esses arranjos fornecem sentidos, orientações, significados ao agente. Toda informação é necessariamente codificada - ou não será informação.

Vimos no entanto como, a todo instante, esses códigos parecem surpreendidos por eventos indesejados, aleatórios. São eventos que, no fundo, estamos aguardando acontecer, mas não sabemos quando, onde, de que forma. O trabalho vivo combinado está lá justamente para tentar evitar que aconteçam ou, quando acontecem, buscar controlá-los ao menor custo de tempo e dinheiro possível. Esta dimensão de incerteza e aleatoriedade é da natureza da informação (Shannon e Weaver, 1975; Atlan, 1992; Dantas, 2001 b). Ela se revela através do evento aleatório, isto é, um evento indicando que há algo diferente, desconhecido ou inexplicado ocorrendo no ambiente à nossa volta ou no objeto de nossa ação, algo que, num primeiro momento, não parece previsto em algum código específico. Vimos acima e voltaremos a discutir em seguida como os operários são motivados pela necessidade de encontrar significados para eventos inesperados ou não-desejados; não, pelos eventos rotineiros e previsíveis.

É necessário que haja alguma repetibilidade e, daí, previsibilidade, para que se possa reconhecer inicialmente um código. A essa repetibilidade denomina-se redundância, com base na qual se pode estabelecer os graus de diferenciação necessários para a extração dos sentidos ou significados contidos no evento transmitido através do código. Isto é, a redundância permite a alguém, diante de uma mensagem na qual faltam alguns itens, "adivinhar os itens faltantes com um grau de acerto superior ao que lograria ao azar" (Bateson, 1998, p. 443).

É necessário também tal redundância codificada para que o agente possa perceber aquele evento diferente e significativo que mobilizará a sua ação. A diferença revela as possibilidades de variação dentro do código, muitas delas, ou a maioria delas, de algum modo previsíveis (as conotações possíveis). Algumas delas, entretanto, serão tão imprevisíveis que se resolverão ou pelo desastre (completa paralisação ou ruptura do processo) ou por alguma solução radicalmente inovadora, capaz de fundar algum novo código - a invenção. Por isto dirá Bateson: informação é "qualquer diferença que introduz uma diferença em algum evento posterior" (Bateson, 1998, p. 407).

\section{Trabalho semiótico}

Umberto Eco, rompendo com a tradição semiológica saussuriana ao mesmo tempo em que revolvia de ponta-cabeça a matriz peirciana da Semiótica, compreendeu a semiose como um processo de trabalho e, daí, recategorizou 
os estudos semióticos conforme os modos de trabalho aí envolvidos. Superando as tradicionais dicotomia significante/significado ou tricotomia signo/interpretante/objeto, Eco (1980) propôs uma classificação para esses modos de trabalho que, com modificações derivadas da nossa pesquisa, apresentamos na Tabela $1^{3}$.

Por que "produzir signos implica um trabalho, quer este signo sejam palavras ou mercadorias" (Eco, 1981, p. 170), haverá um trabalho físico necessário para a produção de uma expressão significativa, equivalente ao tempo de trabalho vivo que, acompanhando Eco, pode ser tipificado em quatro situações: invenção, replicação, ostensão e reconhecimento.

Na invenção criam-se formas de expressão não previstas inicialmente nos códigos, em função de uma ocorrência não relacionada imediatamente a esses códigos. Nas artes são muitos os exemplos, sobretudo se nos lembramos da obra de Manet, Stravinski, Joyce e outros. Na produção capitalista, sobretudo no capitalismo informacional, a invenção (inclusive e necessariamente também semiótica) ser-lhe-á inerente.

Na replicação, reproduzem-se formas de expressão imediatamente relacionadas a algum código. O melhor exemplo é a nossa conversação coloquial, quando utilizamos palavras e frases facilmente reconhecidas nas circunstâncias dadas. A replicação é a situação social e semiótica mais comum, efetuando-se porém a diversos graus (maiores ou menores) de redundância, conforme os códigos, contextos e circunstâncias.

$\mathrm{Na}$ ostensão, um objeto material serve, ele mesmo, como expressão significativa, por intenção do agente, dada uma circunstância. Exemplo: um copo vazio de cerveja levantado na mesa de um bar, indicando ao garçom que traga outro copo cheio.

No reconhecimento, um objeto ou evento material é percebido como expressão significativa por um agente, dada alguma codificação prévia, embora o evento, em si, não fosse intencionalmente significativo. São os casos típicos de impressões digitais, pegadas, sintomas corpóreos de doenças etc. A rigor, todo e qualquer processo comunicativo se inicia com algum evento "indical". É necessário algum contacto, seja verbal, seja táctil, seja ocular, para que qualquer conversação tenha início. É o "reconhecimento" da potencialidade significativa deste primeiro contacto que estabelece a relação interativa que dará seqüência à comunicação, bem como, quase sempre, no mesmo instante, identifica o seu código apropriado. Em outras circunstâncias, o reconhecimento, quando não é remetido a algum código dado, pode resolver-se na invenção.

A relação, identificada por Eco, mais imediata ou menos imediata entre uma forma mental socialmente padrão (tipo) e a sua ocorrência concreta indicaria, sugerimos, menor ou maior incerteza diante de um evento ${ }^{4}$. Na conversação coloquial, uma frase organiza as palavras de tal modo que, na 
circunstância, o seu significado é imediatamente percebido, sem maior esforço, pelos falantes. A incerteza - incerteza quanto ao significado imediato do evento sígnico - é eliminada assim que a frase é concluída. Mas um piscar intermitente, imprevisto, de uma cor esverdeada em um fio translúcido durante um processo produtivo, conforme no tópico "O erro da máquina", é uma ocorrência que não remete, de imediato, a um significado mais claro. Apenas indica um problema, dando origem a todo um processo subseqüente de processamento de informação e produção de significados.

Cada um dos quatro tipos de trabalho físico definidos acima vai se diferenciar entre si conforme essa taxa (maior, menor, quase nenhuma, máxima) de incerteza contida no processo. O reconhecimento pode se dar por indícios, sintomas ou impressões. A ostensão utilizará amostras ou exemplos. A replicação, além da linguagem verbal ("unidades combinatórias", na terminologia de Eco), também poder-se-á fazer por meio de estilização, vetores e ainda outros modos, dentre esses os (destacados em retângulo na tabela) que foram identificados nesta pesquisa e serão apresentados adiante. E a invenção, por fim, será produzida por meio de gráficos, projeções ou calcos.

Tabela 1

Modos de produção sígnica

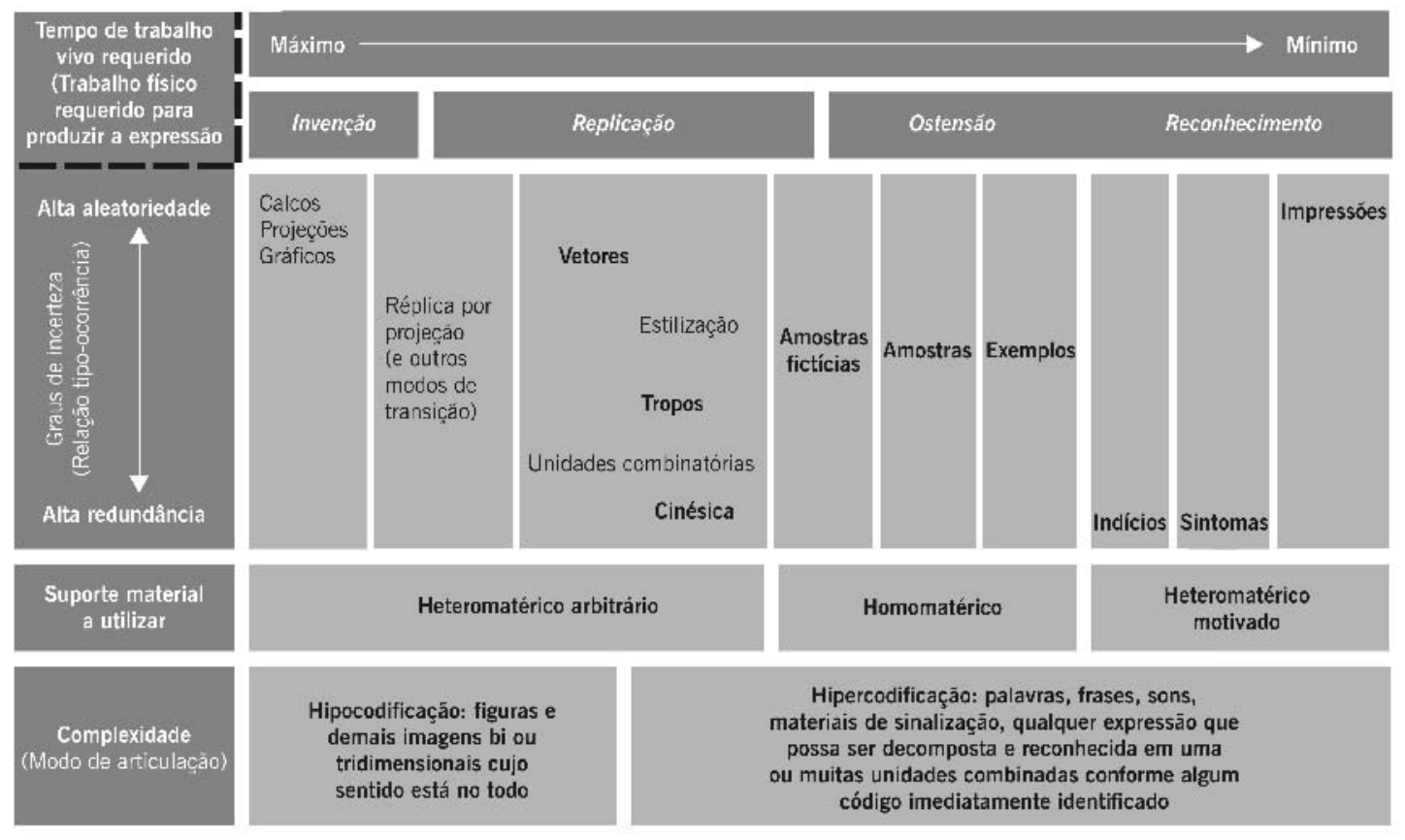

Fonte: adaptada a partir de Eco (1980) 
O trabalho sígnico é trabalho material: efetua, de algum modo, ação sobre a matéria objetiva, transformando-a, além de causar, também, algum desgaste físico do agente e dos meios que ele utiliza para realizar a interação. Logo, o trabalho físico e a taxa de incerteza serão em parte condicionados pela matéria que servirá de suporte ao signo (ou "continuum a formar").

Na maior parte dos casos, a relação entre a expressão e a matéria é um tanto arbitrária: a matéria apenas serve de suporte à comunicação, sendo utilizada e transformada aquela que se mostre mais adequada à ação ou viabilize poupança de tempo na comunicação. A fala, por exemplo, serve-se de vibrações do ar. A escrita, de folhas de papel. Boa parte da produção sígnica contemporânea utiliza-se de suportes de silício semicondutor, sendo, para isto, mediada por uma linguagem binária. A todos estes casos, Eco denominará "heteromatérico arbitrário". A ostensão, por definição, será "homomatérica". Os casos de reconhecimento, por sua vez, são também heteromatéricos mas, aqui, a escolha da matéria não é arbitrária: antes é ela que produz aquilo a ser percebido ou reconhecido como uma expressão significativa. Por isto, estes casos serão ditos "heteromatéricos motivados".

O último dos quatro aspectos identificados por Eco na produção semiótica diz da complexidade interna do código utilizado na expressão, o que também afeta o tempo e a incerteza do processo. No caso de palavras, por exemplo, é possível analisá-las em seus elementos mais simples (as sílabas ou fonemas) que, embora sejam individualmente desprovidos de significação, indicam, pela simples presença de um deles, de imediato um código potencial em utilização. Tanto que, conforme demonstram jogos como palavras cruzadas ou forca, havendo algumas sílabas, pode-se deduzir as demais - é o efeito-redundância do qual falava Bateson, citado mais acima. As imagens, em geral, apesar de conterem muitas formas, linhas, cores etc., ou por isto mesmo, na maioria dos casos não são analisáveis em unidades codificadas. Quase sempre só produzem sentido pelo todo, ou "texto". Haverá ainda muitas outras situações de articulações possíveis, até mesmo de articulação zero (a ausência da bandeira presidencial na frente do Palácio do Planalto significa que o presidente não está presente no prédio).

\section{Análise do processo de trabalho}

Com base nos conceitos já apresentados nos tópicos "Incerteza, aleatoriedade, redundância" e "Trabalho semiótico", podemos retornar à descrição que fizemos de alguns momentos do processo fabril de trabalho e convergir para sua análise e elucidação final. A Figura 3 se nos apresenta um desenho, em tela de computador, de um molde. O valor de uso final será uma maçaneta de porta. Ela pode ser facilmente identificada por duas 
figuras ovaladas no centro do desenho. A linha quadrada com vértices arredondados que contorna o desenho, define os limites do molde. Em seu interior, vemos linhas inteiras e tracejadas de cores pretas, azuis e vermelhas, pequenas circunferências, outras figuras. Obviamente, aí há um código, intradutível a um não-iniciado, mas perfeitamente claro para a engenharia, que projetou o produto, para o técnico (talvez, também, engenheiro), que o desenhou na estação $\mathrm{CAD}$, e para o operário-ferramenteiro, que transformará o desenho (na verdade, uma coleção deles) no molde metálico. Vemos este molde na Figura 4. A produção desse desenho, como vimos antes, resultou de um trabalho coletivo, efetuado em diferentes fases, que se consumou na fabricação artística de um protótipo.

\section{Figura 3}

Desenho de engenharia, em tela de computador (no caso, molde de maçaneta)

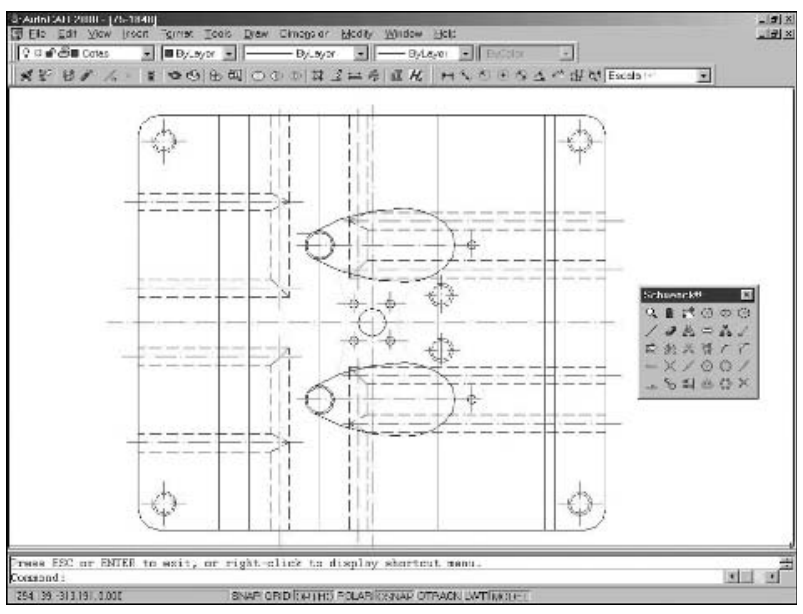

\section{Figura 4}

Molde de maçaneta, podendo-se ver as formas esculpidas conforme o desenho acima

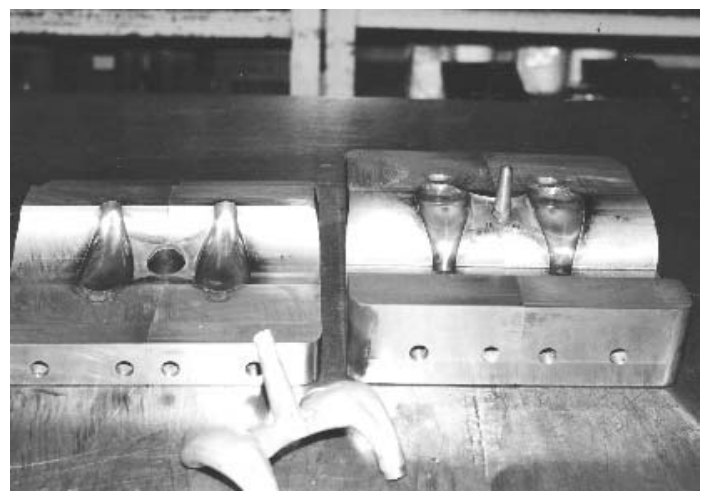


Na estação CAD, inicia-se o processo de codificação fabril do protótipo. Nesta primeira fase, ainda de transição, obtém-se um desenho técnico. Conforme os códigos do desenho industrial que profissionais de nível superior ou médio terão aprendido em suas formações escolar e universitária, mas também terão desenvolvido em suas experiências de trabalho, somados aos códigos específicos do software que utilizam (na Figura 3, podemos ver elementos desse código numa janela de tela à direita), este coletivo executará desenhos nos quais traços, linhas, tracejados, figuras, cores agora significam formas geométricas precisas, larguras, alturas, volumes, distâncias etc. Mesmo com a ajuda da informática, a realização deste trabalho não é trivial. Dependendo da fábrica e do produto, pode consumir o tempo de um dia, mas pode consumir muitos dias, meses, até anos. Ao contrário deste caso que nos serviu para investigação, o mero desenho de um circuito integrado como os que hoje utilizamos em nossos microcomputadores será, por exemplo, um trabalho cuja realização mobilizará dezenas de trabalhadoresengenheiros por um ano ou mais.

Ainda estamos, por enquanto, numa fase de elevada incerteza. Aqui, a taxa de replicação é baixa. O principal modo de trabalho é a projeção, quando "pontos no espaço da ocorrência expressiva [no caso, a tela desenhada do computador] (...) correspondem a pontos selecionados no espaço de um modelo semântico topossensitivo" (Eco, 1980, grifo no original). Em outras palavras, a imagem na mente do trabalhador (a partir do modelo prototipado) é projetada no objeto que servirá de substrato à expressão significativa, através de uma seleção de traços ou pontos que possam, de algum modo convencional, assemelhar-se a essa imagem.

Com base em desenhos assim, o operário-ferramenteiro efetuará a fase seguinte $^{5}$. $\mathrm{O}$ ferramenteiro lerá os desenhos e os replicará na matéria bruta que dará origem ao molde. O código já está formado, bem definido. Mas a natureza heteromatérica deste trabalho demandará todo um tempo necessário à efetuação de cálculos, ajuste de máquina, ou resolução de pequenos problemas próprios a essas situações concretas de transformação material. Se a produção semiótica já entrou em uma fase de replicação, o trabalho combinado ainda está fabricando uma peça original e única. Cada molde é um molde. Aqui, vão se unir tanto a competência semântica (uso da linguagem matemática, reconhecimento de figuras etc.) quanto a habilidade manual dos operários concretos que comandam as máquinas-ferramentas.

Trata-se de uma replicação mas, ao mesmo tempo, de uma transformação: a imagem projetada num desenho bidimensional transmuda-se em imagem escavada em um suporte metálico tridimensional. Concavidades, furos, ressaltos etc. são fatos mecânicos-materiais e, também, significam os traços e figuras vistos no desenho. O operário projeta o que lê no novo suporte, produzindo uma imagem tridimensional que somente por conven- 
ção (ou seja, codificação) poderá ser identificada ao desenho original. É um modo de produção não previsto nas classificações e subclassificações umbertianas, ao que sugerimos denominar replicação por projeção. Encontra-se na exata intercessão entre a invenção e a replicação. A partir daqui, o trabalho combinado tornar-se-á altamente codificado, apenas sendo afetado pelos eventos imprevistos que nele irrompem a todo instante. De aleatório (em maior ou menor grau), o trabalho combinado torna-se redundante (em menor ou maior grau).

As Figuras 5 e 6 oferecem-nos a análise do trabalho redundante, realizado junto às máquinas, conforme já descritos antes neste trabalho em "Do molde à máquina" e "O erro da máquina". Através das atividades de dois trabalhadores concretos, podemos efetuar análises componenciais dos significados atribuídos a aleatoriedades circunstanciais, no interior de um código laboral bem estabelecido, conforme o modelo criado por Eco (1980).

O código fabril está parcialmente contido na mente do operário individual e coletivo, e parcialmente registrado nos desenhos, nos painéis das máquinas, nos moldes, em manuais de produção etc. Como todo código, compõe-se de unidades culturais que se expressam através de suas mínimas unidades significativas. Neste contexto laboral, serão denominados ergonemas.

Articulados e relacionados, seja nas formas topossensitivas de moldes, seja nas formas topológicas de gráficos e diagramas, seja na codificação binária de um programa de computador, qualquer conjunto significativo, ou texto ergonêmico, visará, no chão-de-fábrica, reduzir, ou mesmo eliminar, ambigüidades; prevenir eventos aleatórios indesejáveis; assegurar a reprodução aos milhares de algum modelo de produto, no menor tempo que os materiais e as engrenagens das máquinas o permitirem. Ou seja: o ergonema é uma unidade significativa articulada pelo tempo de produção.

Por outro lado, como vimos, na realidade concreta e cotidiana do processo produtivo, os trabalhadores vêem-se diante de inúmeras interferências aleatórias que lhes afetam os tempos de trabalho. $\mathrm{O}$ operário precisará produzir o significado do ergonema nestas específicas situações. Arranjos sintáticos e semânticos, nas circunstâncias paradigmáticas da ocorrência, fornecem os seus significados denotativos (d) e conotativos (c), orientando as ações práticas correspondentes Quando os ergonemas passam a expressar significados conotativos circunstancializados, vamos chamá-los de ergonsemas. 
Figura 5

Análise da replicação por vetores

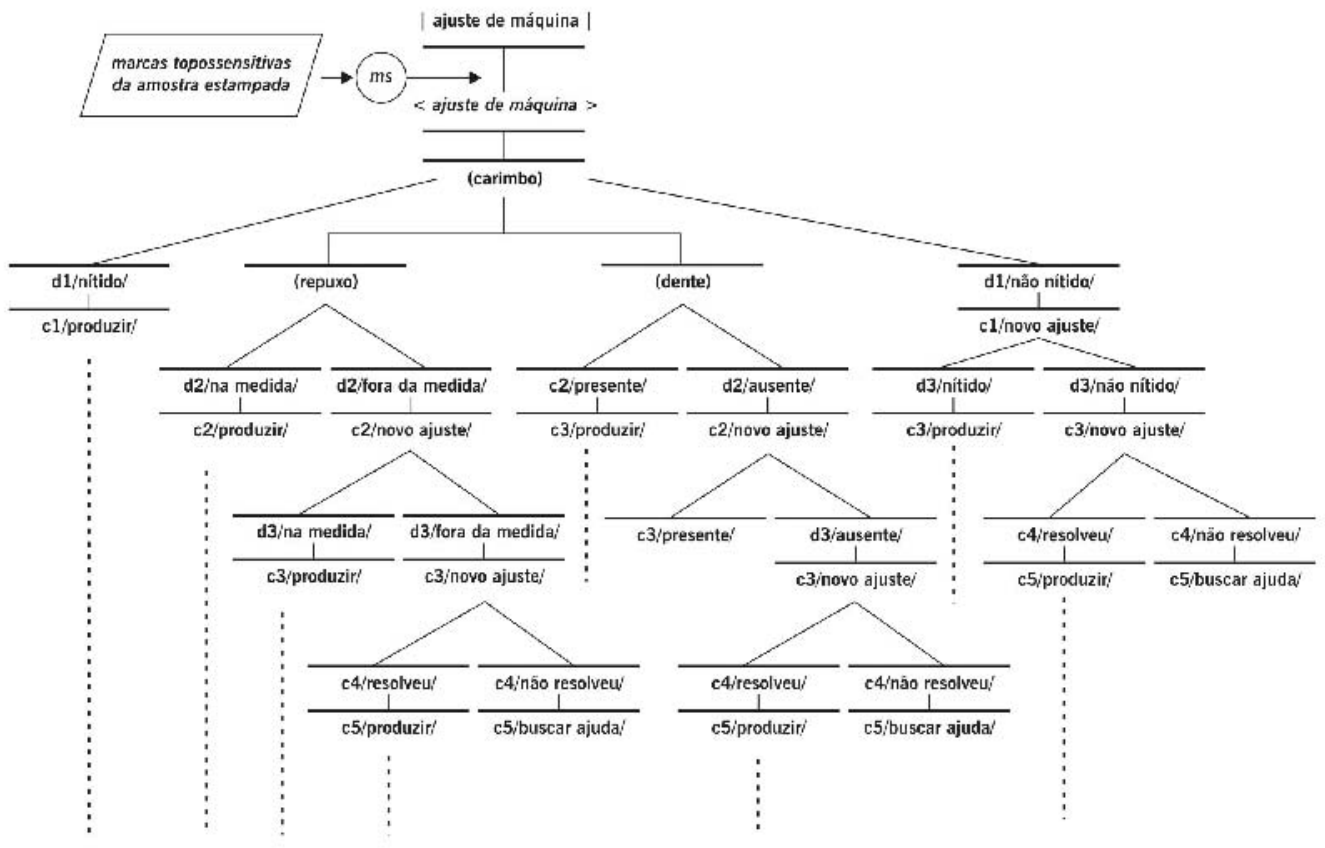

Na Figura 5, o operário está produzindo o ergonema |ajuste de máquina| para uma específica peça. Esta peça, para ele, somente significa algo enquanto "problema" - no caso, os problemas que ela lhe cria no "setape". Ela lhe impõe a sintaxe do processo. Suas marcas sintáticas ( $m s$, na Figura 5) são as formas topossensitivas que ele, em geral, domina de memória. O seu conteúdo (ou, saussurianamente, "significado") reside no comportamento daquelas formas, na circunstância deste "setape" concreto. Este comportamento pode determinar desde a continuação da tarefa, pondo-se a máquina para trabalhar de vez, como pode obrigar a sua interrupção, caso algum defeito não possa ser corrigido durante o ajuste mesmo. Será no decorrer desta incerteza que o ergonema revelará seu real significado semêmico.

Sintaticamente, a peça se define, no ajuste, por um conjunto de elementos que, para o operário, ela deve conter: $\mid$ carimbo $|$,$| repuxo |$,$| dente \mid$, talvez alguns outros, que o trabalhador não nos citou. Mas, no $\mid$ carimbo|, não lhe interessa as \formas numéricas $\backslash$ que nele vê. Estas, como significado numérico, talvez possam ter função semiótica em alguma outra instância do trabalho vivo combinado. Ali, no posto de transformação, elas não passam de optossemas 6 que, no conjunto, formam uma unidade significativa que denotará /está nítido/ ou /não está nítido/. 
O |repuxo|, por sua vez, precisa apresentar uma exata forma. Esta forma possui, aliás, uma medida precisa que o trabalhador conhece e, se necessário, confere através de um taquímetro: 3,4 milímetros de altura. Mas, visualmente, não lhe será difícil conferir se o $\mid$ repuxo| está /mais amassado/ ou /mais aberto/. As formas do repuxo são, pois, também significantes que podem significar /está bom/ ou /está ruim/. o |dente|, por fim, é uma outra forma significativa. Sua ausência denota, de imediato, um /defeito/.

A Figura 5 mostra os percursos de sentidos que o operário pode ter percorrido até conseguir equalizar o seu significado de <ajuste de máquina $>$ (a imagem mental desse ajuste) ao ajuste concreto imposto à máquina. Se os optossemas não se mostram conforme esperado (denotando /não nítido/ ou /fora de medida/), conotarão, de imediato, um /novo ajuste/, alguma ação subseqüente, novos significados, até que < ajuste de máquina $>$ finalmente se traduzirá por /resolveu/ ou, ao contrário, por /buscar ajuda/. No contexto geral, dicionarizado, digamos assim, o ergonema |ajuste de máquina| significará sempre uma espécie de /desafio/, /início de problemas/, /aporrinhações/. Na circunstância, o ergonsema <ajuste de máquina $>$ pode ter expressado /meia-hora/ ou mais de tempo de máquina parada, /tempo perdido/, assim como os problemas reais que foram ou precisam ser corrigidos. Somente após este tempo e da descrição de seus problemas, o operário pôde, afinal, incorporar o sentido concreto, naquele dia, ou naquela hora, do trabalho real que precisou efetuar.

No caso descrito, os optossemas devem orientar o movimento da máquina e são interpretados conforme os movimentos que efetivamente produzem. Tridimensionais, suas formas estimulam e orientam também a atenção do operário, que lhes atribui os significados práticos. Enquanto estas formas não são produzidas exatamente conforme a mente do operário as projetou no objeto, elas introduzem uma situação de alguma incerteza no processo. Estas características fazem deste modo de produção, seguindo Eco (mas, talvez, ampliando o alcance de seu conceito original), uma replicação vetorial. 


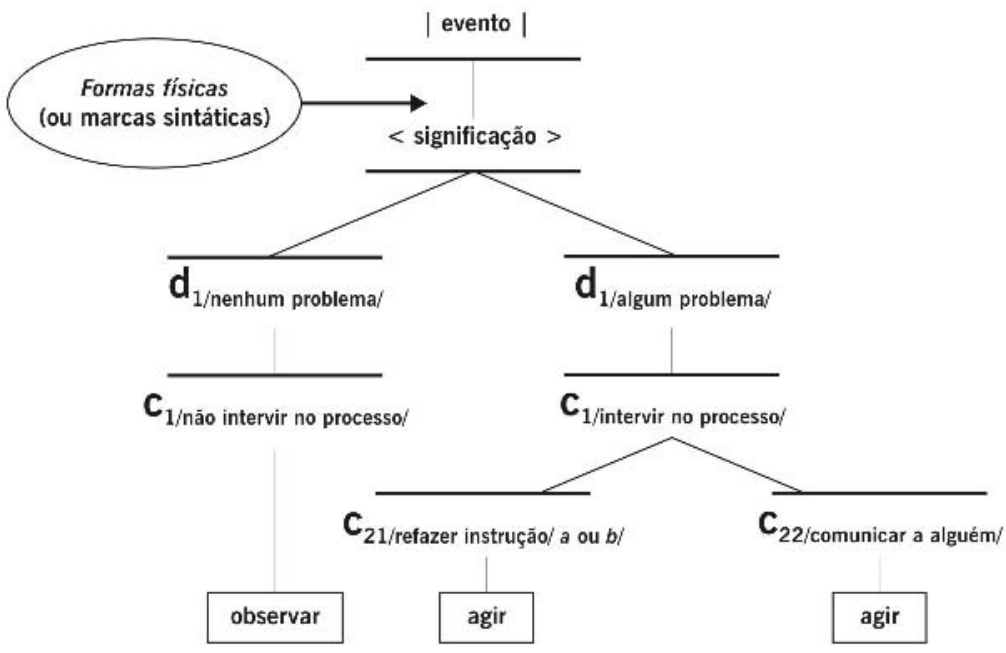

Tendendo ao mínimo

Tendendo ao máximo

Na Figura 6, temos também um processo codificado, semelhante ao anterior. A partir de um primeiro evento, aleatório, o operário busca atribuir significados à ocorrência, em princípio lançando mão de todos os elementos contidos no código laboral que domina. Ele tentará corrigir o comportamento da máquina, através de seus comandos, conferirá mais de uma vez a posição de números e ponteiros em diversos mostradores, seguirá observando, agora atentamente, a matéria em transformação, até certificarse de que tudo voltou ao "normal" ou que, ao contrário, precisará paralisar o processo e convocar outras instâncias do trabalho combinado. O evento, a emissão de energia esverdeada, significou, denotativamente, /algum problema/ e, a partir daí, multiplicam-se diversos graus conotativos expressando as intervenções nos procedimentos da máquina. Quanto mais se desdobrarem as conotações, maior será o tempo perdido nesta circunstância de incerteza.

O traço comum entre estes dois modos descritos de trabalho no chãode-fábrica é sua redundância básica, já que se baseiam em códigos altamente estruturados. Mas os caminhos da produção de significados nestes dois casos diferenciam-se por que cada evento se deu em elos distintos do trabalho combinado. Neste último caso, diremos que se trata de uma replicação tropossêmica (do grego tropos, desvio), já que se origina de um desajuste, desalinhamento, relativamente a uma seqüência (talvez de muitas 
horas) de eventos que se sucediam conforme rigorosamente planejados7. Por isto, para o operário poderia até mesmo se tratar de um longo tempo de tédio e frustração ${ }^{8}$. No caso anterior (replicação vetorial), como o nome da fase de trabalho diz ("setape"), tratava-se, ao contrário, de ainda ajustar a máquina para só então trabalhar, por muitas horas, conforme uma mesma e repetitiva seqüência de eventos.

\section{Conclusões}

A criatividade, a subjetividade, a tomada de decisões estão presentes em quase todos os elos do trabalho vivo combinado 9 , embora possam variar os graus de tratamento de informação significativa próprios a cada elo, em função de suas respectivas taxas de incerteza e redundância. Às circunstâncias de elevada incerteza e hipocodificação, definidas pelos modos de invenção (que incluem a prototipação) e de replicação por projeção, dissemos tratar-se de trabalho aleatório. Àquelas nas quais um dado código laboral circunscreve os limites de busca, definidas pelos demais modos de replicação ou ainda de reconhecimento, dissemos tratar-se de trabalho redundante. Na primeira, está pressuposto que a informação total possível de se produzir no processo não está dada a priori. Na segunda, embora esteja pressuposto deter-se a informação total sobre o processo, também está dada a possibilidade de ocorrências aleatórias que, caso se efetivem, vão indicar um certo grau de ignorância sobre todas as condições do sistema. Em síntese, no trabalho redundante, detém-se não a informação total mas uma condição maior ou menor de controle sobre suas possíveis ocorrências. No mundo sistêmico real, sempre haverá algum grau de ignorância a respeito de todos os eventos que possam afetar um dado sistema, sendo esta ignorância resolvida por $a b d u c ̧ a ̃ o 10$, isto é, por um método interpretativo tipicamente semiótico.

O molde define e sintetiza a passagem do trabalho aleatório ao redundante. Ele expressa aquele momento em que a quantidade muda a qualidade: de movimentos de trabalho cujos elementos e tempos de busca estão apenas nebulosamente definidos (não-quantificáveis a priori), a movimentos cujos elementos já podem ser razoavelmente mapeados e o tempo deverá sofrer algum tipo de controle e mensuração. A unidade do processo segue assegurada pelo "princípio do cálculo" mas, se identificamos aqui um salto de qualidade, não estamos tratando da "estrutura da consciência" - posto que esta não mudou -, mas de limiares sistêmicos, conforme a Figura 6. A firma, enquanto unidade de capital, pode ser dividida, grosso modo, em três subsistemas ou "níveis de organização", no conceito de Atlan (1992), classificados por Valle (1991), como níveis de 
"macrodecisões", "mesodecisões" e "microdecisões". Através do trabalho vivo aleatório que põe em movimento nos níveis de macro e mesodecisões (atividades estratégicas e gerenciais), a unidade de capital relaciona-se, exogenamente, com a sociedade e o mercado e, endogenamente, com o seu nível de microdecisões, isto é, com o chão-de-fábrica. Através do trabalho vivo redundante que põe em movimento no nível de microdecisões, todo o conjunto da unidade de capital relaciona-se com o trabalho morto de transformação material. O trabalho vivo redundante é, pois, o elo necessário de comando e controle do trabalho combinado total sobre a transformação material que as máquinas executam.

A Figura 7 mostra o fluxo de informações no interior desse sistema. Ele é crescentemente redundante quanto mais se aproxima do trabalho morto e crescentemente aleatório quanto mais se aproxima dos limiares externos da firma. Correspondentemente, no eixo da abscissa, os trabalhos sígnicos realizar-se-ão por replicação quanto mais próximo estiverem do trabalho morto, ou, por invenção, quanto mais próximo estiverem dos limiares externos. Observe-se que tropos e vetores, eventos aleatórios que ameaçam introduzir alguma desordem no sistema, tanto podem ser controlados e reinseridos no fluxo redundante ainda no nível das microdecisões, quanto podem "subir", num processo de crescente produção de informação significativa, para os níveis de meso e macrodecisões. Já o fluxo definido pelo trabalho sígnico de projeção está desenhado a partir do limiar entre as micro e mesodecisões porque, como já explanado antes, trata da construção do molde. O fluxo da prototipação, por sua vez, resultando de interação entre os níveis de meso e macrodecisões, está situado no limiar entre estes dois subsistemas, mas deve, ao longo de seu processo, penetrar nos ambientes sociais ou econômicos além dos limites da firma, já que haverá de se inspirar nas tendências de mercado, nos gostos sócio-culturais, inclusive em testes efetivamente realizados junto a potenciais consumidores.

Tratando informação significativa, enquanto a máquina transforma a matéria, o tempo do trabalho vivo descola-se do tempo do trabalho morto ou de transformação material direta. Este tempo de transformação pode ser predefinido e será reduzido a um mínimo irredutível, em função dos materiais a serem transformados e das tecnologias de transformação disponíveis. Mas o tempo do trabalho vivo (tempo de atividade mental) será sempre um tempo de incerteza, de um máximo aceitável nas fases de concepção e projeto a um mínimo inescapável, nem que seja algum instante binário, nas fases de observação e controle.

O tempo de máquina é um tempo supostamente predeterminado. $\mathrm{O}$ trabalho vivo é convocado quando necessário para recolocar este tempo sob controle, devido a disfunções da máquina. A duração desta intervenção não pode ser previamente cronometrada com rigor, como as análises compo- 
nenciais apresentadas aqui em "Análise do processo de trabalho" podem ter evidenciado. Do mesmo modo, muito menos, serão previamente definidas no tempo todas as atividades de criação e invenção próprias das etapas de pesquisa, projeto e desenho. É óbvio, e ninguém ignora, que qualquer firma e, mesmo, qualquer indivíduo humano buscam estabelecer "prazos" para a consecução de suas tarefas. É um necessário esforço para controlar o tempo - e o dinheiro... Não raro, para cumprir prazos, trabalhamos noite adentro, fins de semana, feriados... É a confissão da impossibilidade de o trabalho criativo poder ser submetido a rígidos controles redundantes.

Para encerrar, estamos em condições de sugerir que uma das principais características da atual nova fase de desenvolvimento do capitalismo que testemunhamos nascer é sua tendência a eliminar uma grande dimensão de trabalho vivo redundante, substituindo-o por trabalho morto de processamento da informação. Isto implica dizer que vários elos de trabalho combinado que se interpõem entre a realização de um molde e o seu ajuste à máquina estão sendo suprimidos. Quando não, o próprio molde vem a ser ele mesmo transcrito em linguagem digital - torna-se "pura" informação para nesta forma comandar a máquina. Quanto mais o capital objetiva e materializa trabalho redundante, mais a sua valorização funda-se tãosomente no trabalho concreto, desfazendo-se do trabalho abstrato. É o que observa Bolaño (2000) ao discutir o valor do trabalho artístico: o valor mercantil de um produto artístico (cinematográfico, fonográfico etc.) é o trabalho concreto realizado pelos artistas. É a interpretação, o "carisma", as emoções, os símbolos estéticos que o artista expressa, são esses valores "intangíveis" que levam alguém a comprar um $\mathrm{CD}$, assistir a um filme, ler um livro. O suporte material, aí, já não vale quase nada, como bem o demonstra a intensa troca de arquivos gratuitos de músicas ou filmes pela internet, ou os milhares de camelôs ditos "piratas" que os vendem a preço vil, nas calçadas das grandes cidades, em todo o mundo, sobretudo nas da periferia pobre. E não precisamos falar apenas da obra artística: as réplicas "piratas" de tênis Nike, de canetas Mont Blanc, de bolsas Vuiton e até do Viagra demonstram que o valor incoporou-se ao trabalho concreto de artistas, estilistas, cientistas etc., na medida em que os processos químicomecânicos replicativos, dada uma matriz ou alguma fórmula original, já quase não demandam prolongar-se o tempo de trabalho combinado de corpo além daquele necessário à criação. 
A firma como um sistema de informações significativas (produtivas)

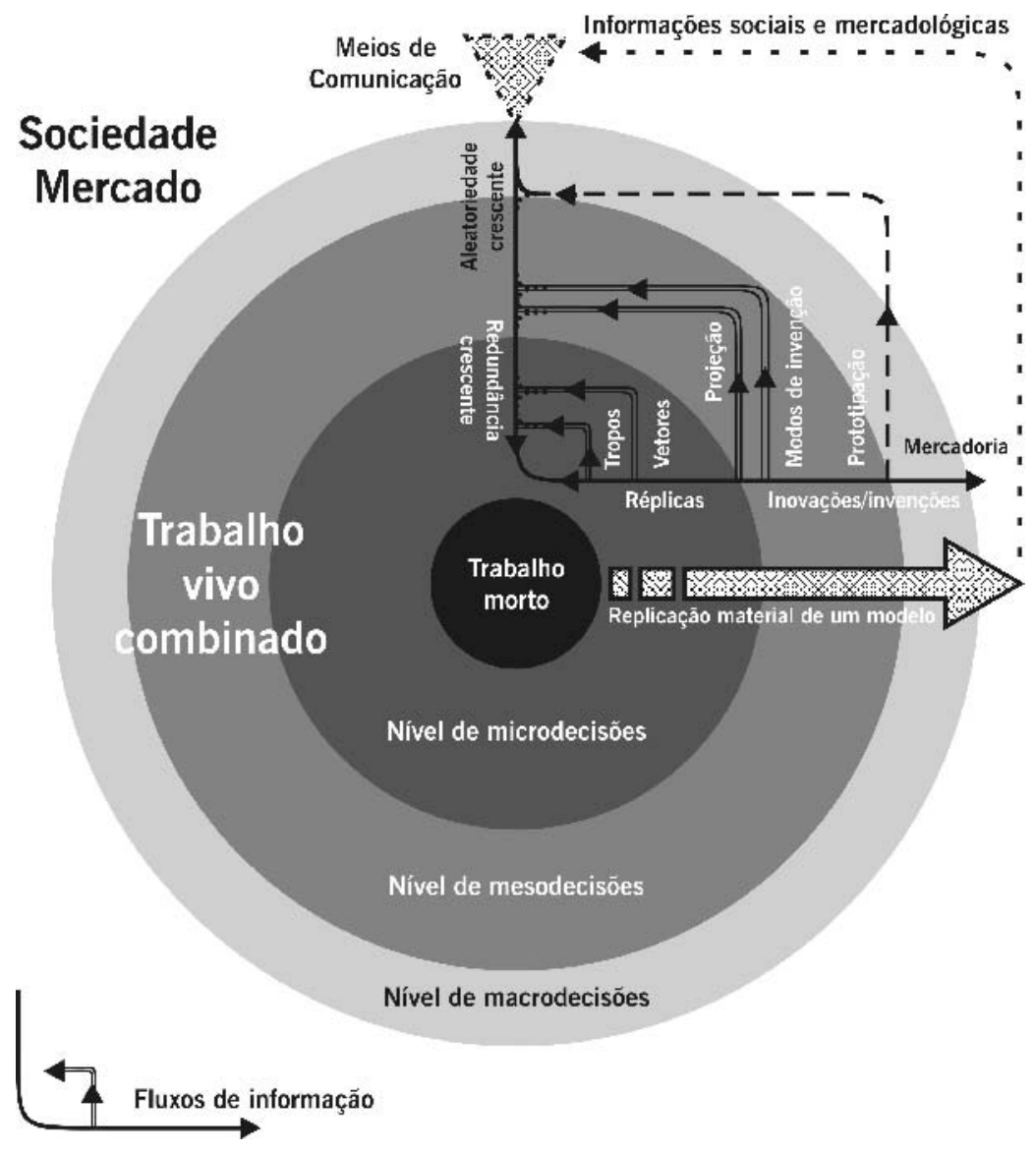

O capital, cada vez mais, comercializa marcas, prazeres, gostos estéticos, estilos de vida. Nisto, o valor de troca é o valor de uso - menos que uma contradição em termos, trata-se de uma sintese. O capital-informação (Dantas, 1999; 2001a; 2001b; 2003; 2006), ou cognitivo (Azaïs et al. 2001), consumou aquele processo, já identificado por Marx, de apropriação, pelo capital, do valor de uso do trabalho ao incorporar em si o trabalho ele mesmo. O capital, esta contradição em processo, chegou a um estágio no qual anulou o valor de troca da mercadoria, logo a mercadoria como tal. Mas se continua a acumular e crescer - e continua a acumular e crescer - é porque, agora, apóia-se nas rendas informacionais extraídas dos monopólios que logra impor sobre o conhecimento produtivo, através dos cada vez mais abrangentes e draconianos direitos intelectuais (Dantas, 2006).

Mas estas são questões para serem discutidas por uma Economia Política da Informação. Neste artigo, preocupamo-nos em mostrar como o trabalho informacional pode ser semioticamente descrito e analisado. Esta 
análise nos esclarece que, de algum modo, os elementos básicos desta nova fase do capitalismo já estavam presentes, pelo menos latentes, na fase anterior. Talvez não fossem ainda bem compreendidos...

Observou Lucas:

“A dissociação entre o trabalho manual e o trabalho intelectual, operada pela grande indústria desenvolvida pelo capitalismo, não tem existência mais que social. Justificada pela famosa frase endereçada por Taylor aos trabalhadores 'não lhes pedimos que pensem, pois outros aqui são pagos para isto' - ela fundou o erro de gerações de ergonomistas que construíram suas análises com base nesta separação. Ora, constata-se que a percepção de sinais não é somente uma atividade física, mas implica funcionamento do cérebro, solicitando-lhe excessiva função perceptiva que o fatiga e deteriora suas capacidades intelectuais. Mas, por outro lado, o trabalho manual repetitivo também fatiga o cérebro. Existem pois aspectos mentais no trabalho físico. A capacidade de prestar atenção, a manutenção da atenção solicitam atividade nervosa superior (Lucas, 1974, p. 161).

Poderia ter acrescentado, além dos ergonomistas, gerações de marxistas...

Em suma, trata-se de reconhecer que a sociedade capitalista industrial moderna é, desde os seus primórdios, uma "sociedade do conhecimento". A relação entre o capital e o trabalho sempre foi uma relação de apropriação, pelo capital, do conhecimento para a produção detido pelo trabalho, nisto empregando, e não podendo deixar de empregar, o corpo que dá suporte à mente que trabalha. Por outro lado, aí sim, os arranjos produtivos e as relações sócio-jurídicas que se estabelecem nessa interação vieram mudando ao longo dos últimos 200 anos, em função de um amplo conjunto de variáveis tecnológicas, políticas, econômicas e culturais, boa parte delas, ou a maior parte delas, nascida no interior mesmo dessa relação.

$\mathrm{Na}$ transição atual, uma de suas principais variáveis seria a introdução da linguagem digital mediando a relação entre o trabalho vivo combinado e a transformação material. Tal, de modo algum, estaria suprimindo o trabalho vivo no processo de produção de valores mas se, por outro lado, isto leva à superação de seus tempos e modos redundantes, estamos sendo convidados a repensar inúmeros outros aspectos políticos, econômicos ou culturais da sociedade em que vivemos. Nesta hora de tantos desafios intelectuais e políticos, caberia recuperar as lições metodológicas do primeiro Lukács:

“Para compreender a mudança, o pensamento deve ir além da separação rígida dos seus objetos; deve pôr no mesmo plano da realidade as relações entre eles e a interação entre estas 'relações' e as 'coisas'. Quanto mais nos afastamos da 
simples imediaticidade, mais se alarga a rede destas 'relações', mais integralmente as 'coisas' se incorporam no sistema destas relações e mais a mudança parece perder o seu carácter incompreensível, despojando-se da sua essência aparentemente catastrófica, e tornando-se, assim, compreensível. Mas isto só se dá caso esta superação da imediaticidade torne os objetos mais concretos, caso o sistema conceptual das mediações a que assim se acede seja (...) a totalidade da experiência" (Lukács, 1989, p. 173-174).

\section{Notas}

1 Professor do Departamento de Comunicação da Pontifícia Universidade Católica do Rio de Janeiro (PUC-Rio) onde coordena o Núcleo de Pesquisa sobre TV Digital. Doutor em Engenharia de Produção pela Coppe-UFRJ. <marcosdantas@com.puc-rio.br>

2 A notação adotada tem as seguintes convenções: |palavra|, entre barras verticais, identifica um termo ou frase 'significante' (ou 'forma de expressão'); /palavra/, entre barras inclinadas, identifica um termo ou frase utilizados como 'significado' em geral, ou dicionarizado (ou 'forma do conteúdo'); < palavra>, entre sinais de 'maior que' e 'menor que', identifica um termo ou frase usados como 'significado na circunstância', ou significado 'real' diante da ação; e \palavra\, entre barras retroinclinadas, indica formas físicas, figuras, traços, sinais 'potencialmente significativos' (objetos materiais).

3 Na semiologia de Ferdinand de Saussure e, por extensão, em toda a tradição estruturalista, o signo apresenta duas dimensões: a "significante", que corresponde ao objeto material (acústico, visual, qualquer outro sensível) do signo; e a do "significado", imagem ou conceito mental relacionado àquele objeto. Hjelmslev recategorizou essa dicotomia numa chave neokantiana, traduzindo o significante por "forma de expressão" e o significado por "forma de conteúdo", termos que serão preferencialmente adotados por Eco. Já a semiótica de Peirce associa o objeto material ao seu conceito geral de "signo"; ao conceito ou imagem mental do signo chama "interpretante" (o sujeito que interpreta) e relaciona-os ambos a um terceiro elemento, àquilo que signo e interpretante remetem, ou "objeto".

4 A proposta de Umberto Eco cinge-se a reconhecer que pode ocorrer uma aderência maior ou menor da expressão efetivamente utilizada a um modelo predefinido e reconhecível pelos que dominam um dado código. Identifica essas condições de aderência com dois termos nascidos de sua criatividade e sofisticação intelectual: ratio facilis (fácil aderência) e ratio difficilis (difícil aderência). Muitos casos situar-se-ão a meio caminho destes dois extremos, mas as invenções, por definição, serão sempre casos de ratio difficilis e as palavras dicionarizadas e os sintomas serão casos de ratio facilis. Propusemos, no propósito, entre outros, de relacionar os modos de produção semióticos à teoria da informação e ao trabalho informacional, substituí-los pelos mais usuais e contemporâneos conceitos, com as expressões correspondentes, de 'taxas de incerteza' e de 'redundância'.

5 Como observamos antes, o avanço da automação informatizada tende a transferir os dados do CAD diretamente para as máquinas de fabricação dos moldes, substituindo, nesta 
fase, trabalho vivo por trabalho morto. Mas tivemos, por outro lado, durante a nossa investigação, a oportunidade de observar, em uma fábrica mecânica de altíssima tecnologia e precisão, cuja produção é de baixa escala e sob encomenda, os operários comandando enormes máquinas de estampar, a partir de uma programação que nelas introduziam conforme a leitura que faziam em sofisticados diagramas. Infelizmente, não nos foi possível desenvolver pesquisa maior nesta empresa.

6 Formas significativas visuais que contêm significados pelo modo como são 'vistas', independentemente de, em algum outro contexto, poderem conter significados em função de outros conteúdos que possam transmitir. Numa fábrica, devido à baixa escolaridade de muitos trabalhadores, é comum se atribuir significados aos objetos tão-somente devido à sua forma externa e, não a algum 'nome técnico' mais preciso pelo qual possa ser conhecido em ambientes intelectualmente mais completos.

7 Existirão ainda outros modos de replicação que não serão tratados aqui. Na 'replicação cinésica', por exemplo, será o próprio movimento de corpo do trabalhador que deverá auto-replicar-se seguidamente, por muitas horas, de modo a assim também replicar, em um segundo suporte material, formas de expressão as mais similares possíveis às formas que lê em um primeiro suporte dado. É o caso, entre outros, do trabalho das datilógrafas.

8 É o que investigou C. Dejours (1993; 1997) em pesquisas nas quais relata como o trabalhador, para fugir ao tédio, desenvolve estratégias comportamentais que se demonstram funcionalmente eficazes (pois aperfeiçoam sua capacidade para perceber as disfunções da máquina), e psicologicamente gratificantes, ao lhe permitirem minorar o tédio dessas horas redundantes de trabalho.

9 Como dito na nota $\mathrm{n}^{\circ} 6$, não abordamos, neste texto, a replicação cinésica, cuja elevada redundância quase não dá margem à subjetividade do trabalho, exceto, talvez, como "erro". Não ocorrendo, porém, em todas as indústrias, mas apenas naquelas que incluem uma fase final de montagem, e não envolvendo, exceto eventualmente, de modo muito residual, algum processo de transformação, este modo de replicação só pôde merecer a importância e dimensão analítica que se lhe atribuiu porque, realmente, durante um certo estágio do desenvolvimento capitalista, revelou-se grande empregador de mão-de-obra desqualificada. De qualquer modo, veio a ser, não por acaso, o mais atingido pelo processo atual de substituição de trabalho vivo redundante por trabalho morto de processamento da informação.

10 "Uma abdução é um método de formar uma predição geral sem nenhuma certeza positiva de que ela se verificará, seja num caso especial ou normalmente, sendo sua justificativa a de que é a única esperança possível de regular racionalmente nossa conduta futura, e que a indução a partir de experiências passadas nos encoraja fortemente a esperar que ela seja bem sucedida no futuro" (Peirce, 1977, p. 60). 
ATLAN, Henri. 1992 [1979]. Entre o cristal e a fumaça. Rio de Janeiro: Jorge Zahar Editores.

AZAÏS, Christian; CORSANI, Antonella; DIEUAIDE, Patrick. 2001. Vers un capitalisme cognitif. Paris: L'Harmattan.

BATESON, Gregori. 1998 [1972]. Pasos hacia una ecología de la mente. Buenos Aires: Ediciones Lohlé-Lumen, trad., p. 443.

BAUDRILLARD, Jean. (s/d) [1972]. Para uma crítica da economia política do signo. São Paulo, SP: Martins Fontes, trad.

BOLAÑO, César. 2000. Indústria cultural, informação e capitalismo. São Paulo, SP: Hucitec-Editora Pólis.

BOURDIEU, Pierre. 1982. A economia das trocas simbólicas. São Paulo, SP: Perspectiva, trad.

. 1983a [1972]. Esboço de uma teoria da prática. In: ORTIZ, Renato (org.), Pierre Bourdieu. São Paulo, SP: Ática, trad., p. $46-81$.

. 1983b [1976]. O campo científico. In: ORTIZ, Renato (org.), Pierre Bourdieu. São Paulo, SP: Ática, trad., p. 122-155.

BRAVERMAN, Harry. 1981 [1974]. Trabalho e capital monopolista. Rio de Janeiro, RJ: Zahar Editores, trad.

BURAWOY, Michael. 1979. Manufacturing consent. The University of Chicago, EUA.

CORIAT, Benjamin. 1976. Science, technique et capital. Paris: Éditions de Seuil.

DANTAS, Marcos. 1999. "Capitalismo na era das redes: trabalho, informação e valor no ciclo da comunicação produtiva". In: LASTRES, Helena e ALBAGLI, Sarita. Informação e globalização na Era do Conhecimento. Rio de Janeiro: Campus, p. 216-261.

. 2001a. "L'information et le travail:

la valorisation et l'accumulation dans le cycle de la communications productive". In: AZAÏs et al. 2001. Vers un capitalisme cognitif. Paris: L'Harmattan, p. 76-89. 2001b. Os significados do trabalho: uma investigação semiótica no processo de produção. Tese de Doutoramento, Coppe-UFRJ, Rio de Janeiro.

. 2003. "Informação e trabalho no capitalismo contemporâneo". Lua Nova, $\mathrm{n}^{\circ} 60$, p. 5-44.

2006. "Informação como trabalho e como valor". Revista da Sociedade Brasileira de Economia Política, ${ }^{\circ} 19$, p. 44-72.

DÉBORD, Guy. 1997 [1992] [1967]. A sociedade do espetáculo. Rio de Janeiro: Contraponto, trad.

DEJOURS, Christophe. 1993. "Inteligência operária e organização do trabalho: a propósito do modelo japonês". In: HIRATA, Helena (org.). Sobre o "modelo" japonês. São Paulo, SP: Edusp, p. 281-309.

DEJOURS, Christophe. 1997 [1995]. O fator humano. Rio de Janeiro: Editora Fundação Getulio Vargas, trad.

ECO, Umberto. 1980. Tratado geral de semiótica. São Paulo, SP: Perspectiva, trad. 1981 [1973]. O signo. Lisboa: Editorial Presença, trad.

HOBSBAWN, Eric. 1997. A era das revoluções. São Paulo, SP: Paz \& Terra, $10^{a}$ ed., trad.

LANDES, David S. 1994 [1969]. Prometeu desacorrentado. Rio de Janeiro: Nova Fronteira, trad.

LUCAS, Yvette. 1974. Codes et machines essais de sémiologie industrielle. Paris: PUF.

LUKÁCS, Georg. 1989 [1922]. História e consciência de classe. Rio de Janeiro: Elfos, trad.

MARX, Karl. 1973 [1953]. Elementos fundamentales para la crítica de la Economía Política. Siglo Veintiuno Argentina Editores, 3 vols., $4^{a}$ ed. . 1983 [1867]. O capital. São Paulo, SP: Abril Cultural, 4 vols., trad. . (s/d) [1969]. Capítulo VI inédito de O capital. São Paulo, SP: Moraes.

MAURICE, Marc. 1998. "La question du 
changement technique et la sociologie du travail". In: de COSTER, Michel e PICHAULD, François (eds.), Traité de sociologie du travail. Paris: DeBoeck Université, p. 247-267.

NAVILLE, Pierre. 1963. Vers l'automatisme social?. Paris: Éditions Gallimard.

PEIRCE, Charles Sanders. 1977. Semiótica. São Paulo, SP: Perspectiva, trad.
ROSDOLSKY, Roman. 2001 [1968]. Génese e estrutura de O Capital de Marx. Editora Contraponto, Rio de Janeiro, trad.

SHANNON, Claude e WEAVER, Claude. 1975 [1949]. A teoria matemática da comunicação. Rio de Janeiro: Difel, trad.

VALLE, Rogério (1991). "Automação e racionalidade técnica", Revista Brasileira de Ciências Sociais, ano VI, n. ${ }^{\circ}$ 17, Anpocs-Relume-Dumará, Rio de Janeiro, RJ, p. 53-67.

Recebido em 07/06/2006

Aprovado em 20/09/2006 